\title{
EMERGING ALTERNATIVES TO MUTUAL FUNDS: UNIT INVESTMENT TRUSTS AND OTHER FIXED PORTFOLIO INVESTMENT VEHICLES
}

\author{
THOMAS S. HARMAN*
}

Thomas Harman offers a comprehensive analysis of the Unit Investment Trust. First, he defines the trust, examining the mechanics and participants associated with it. He then traces the development of the trust since its inception as a "fixed trust." Next he discusses the regulation of the trust by the Securites Acts of 1933 and 1940. Finally, he compares the unit investment trust with other investment vehicles.

The unit investnient trust (UIT) has experienced many changes since its inception some sixty years ago as a "fixed trust." Some of the early fixed trusts were created as a result of the distrust of the excesses of the managed investinent companies revealed in the aftermath of the Depression. Others were created because of the diversification they provided and because they allowed sinall investors to obtain an interest in a portfoho of securities that had becoine unaffordably expensive. Today such trusts compete with mutual funds for many consumers' investınent dollars. In fact, by the end of 1986, UITs held assets worth approximately $\$ 110$ billion, whereas mutual funds (other than money market funds) held assets worth $\$ 424$ billion. ${ }^{1}$ The growth in the UIT industry has occurred rapidly. At the beginning of 1970, inutual funds had assets of $\$ 52$ billion, whereas UITs had assets of less than half a billion dollars. By the beginning of 1975 , mutual fund assets had declined to $\$ 38$ billion and UIT assets had grown to $\$ 4.4$ bilhon. By the end of 1980 , mutual fund assets had risen to $\$ 138$ billion and UIT assets had jumped to $\$ 41$

* Chief, Office of Disclosure and Adviser Regulation, Division of Investment Management, Securities and Exchange Commission. The author gratefully acknowledges the assistance of Jeffrey L. Steele, Adjunct Professor, Georgetown University Law Center, for reading and commenting on this article.

The Securities and Exchange Commission, as a matter of policy, disclaims responsibility for any private publications by any of its employees. The views expressed herein are those of the author and do not necessarily reflect the views of the Commission or the author's colleagues on the staff of the Commission.

1. INVESTMENT Co. INST., 1987 MUTUAL Fund FACT BOOK: INDUSTRY TRENDS AND STATISTICS FOR 1986, at 60; INVESTMENT Co. INST., REPORT ON TOTAL OUTSTANDING UNIT INVESTMENT TRUSTS FOR THE YEAR 1986 (1987). 


\section{billion. $^{2}$}

A UIT is an unmanaged investinent vehicle that invests in securities and sells interests ("urnts") in itself. As such, it ineets the definition of "investinent coinpany" in section 3 of the Investinent Coinpany Act of 1940 (the 1940 Act). ${ }^{3}$ The 1940 Act specifically defines a UIT as an investinent coinpany, organized under a trust indenture, that has no board of directors and that "issues only redeeinable securities, each of which represents an undivided interest in a unit of specified securities."4 While the UIT, like a mutual fund, issues redeenable securities, it nonetheless is different from a mutual fund in that the entity sponsozing the UIT nearly always creates a secondary inarket in the uints sold by the trust. Both the sponsor and the trust benefit froin the creation of the secondary inarket. The sponsor receives a sales charge on each unit resold in the secondary inarket, often at a higher rate than that received on units sold in the primary inarket. Unitholders enjoy a trust that does not have to deplete itself of its assets-possibly under disadvantageous circumstances-to meet redemptions. Redeinptions of portfoho securities could cause preinature termination of the trust if substantial enough or, nore likely, create distributions of principal to reinaining uintholders that could be reinvested ouly less advantageously or upon payinent of a sales load or cominission. ${ }^{5}$

UITs are attractive investinents because they offer hquidity and diversity at an affordable price. They allow investors of even inoderate neans to own an interest in a pool of diversified securities and, because they issue redeemable securities, they allow investors to liquidate their investnients quickly and avoid inany of the inarket's vagaries. While a mutual fund also offers diversification and hquidity, the UIT can provide those attributes at a lower cost because it has no investinent adviser to whoin it inust pay an annual inanagement fee. Moreover, because the UIT has a relatively fixed portfolio, the brokerage commissions it incurs are small in coinparison to those of a inutual fund, the portfoho of which often changes. Finally, because of its relatively fixed portfoho, the UIT offers a "known" return. Conversely, a inutual fund's investinent return 1nay rise or fall as it trades its portfoho or invests additional proceeds from new shareholders.

2. Wiesenderger INV. Cos. SerV., INVEstMent CoMpanies 1981, at 12, 563, 594, 598; WiESENBERGER SERVS., INC., INVESTMENT COMPANIES 1975, at 49; WIESENBERGER SERVS., INC., INVESTMENT COMPANIES 1970, at 43.

3. 15 U.S.C. $\S 80 \mathrm{a}-3$ (1982).

4. Id. $\S 80 \mathrm{a}-4(2)$.

5. Unitholders liquidating their investment also used to benefit by receiving a slightly higher price through the secondary market than through redemption. See infra notes 228-30 and accompanying text. 
UITs now invest in a variety of securities. Many invest in municipal bonds, but others invest in mortgage-backed securities. A third type of UIT invests in corporate securities, particularly preferred stock and corporate bonds. Although the vast majority of UITs invest in either municipal or corporate bonds, ${ }^{6}$ some UITs even invest in equity securities. In contrast, the early UITs essentially served as vehicles through which one could invest in common stocks, particularly securities histed on the New York Stock Exchange. ${ }^{7}$ The common stocks tended to represent a cross section of various issuers, although a nuniber of early UITs specialized in the equity securities of banks, railroads, insurance, public utility or oil companies. ${ }^{8}$

Because UITs, unlike mutual funds, have no imvestment adviser or board of directors, certain provisions of the 1940 Act clearly are irrelevant to them. Section 15, which governs the investment company's contract with the adviser, and sections 10 and 16, which govern an investment company's board of directors, are just a few examples. 9 Section 18's extensive regulation of an investment coinpany's capital structure is also irrelevant to UITs, because that provision applies only to manageinent mvestment companies. ${ }^{10}$ Because a UIT is an essentially static entity, the provision of the 1940 Act that governs an imvestinent company's transactions with its affiliates is also mostly irrelevant.11 This static nature has even been recognized in the context of periodic reporting to the Securities and Exchange Commission (the Commission); while mutual funds must file reports semi-annually with the Commission, UITs need only file annually. ${ }^{12}$ Moreover, because the 1940 Act requires only manageinent investment conipanies to issue voting stock, ${ }^{13}$ the proxy provision of the 1940 Act is also largely irrelevant. UITs are, however, subject to certain miportant provisions under the 1940 Act. ${ }^{14}$

6. UITs investing in debt securities hold nearly $\$ 108$ billion of the $\$ 110$ billion in UITs. INVESTMENT CO. INST., REPORT ON TOTAL OUTSTANDING UNIT INVESTMENT TRUSTS FOR THE YEAR 1986 (1987).

7. Investment Trusts and Investment Companies: Hearings on S. 3580 Before a Subcomm. of the Senate Comm. on Banking and Currency, 76th Cong., 3d Sess. 184 (1940) [hereinafter Hearings $3580]$.

8. Securities and EXChange Comm'N, Investment TRUsts and INVESTMENT CoMpaNIES: FIXED AND SEMIFIXEd INVESTMENT TRUSTS 279 (1940) [hereinafter FIXED TRUST REPORT] (pursuant to section 30 of the Public Utihty Holding Company Act of 1935); M. WiLliams, INVESTMENT TRUSTS IN AMERICA 34 (1928). Some fixed trusts even "specialized" by investing in bonds. FIXED TRUST REPORT, supra, at 279.

9. 15 U.S.C. $\S \S 80 a-10,-15,-16(1982)$.

10. Id. $\S 80 \mathrm{a}-18$.

11. Id. $\S 80 \mathrm{a}-17$.

12. 17 C.F.R. $\S \S 270.30 \mathrm{a}-1, .30 \mathrm{~b} 1-1$ (1987).

13. 15 U.S.C. $\$ 80 \mathrm{a}-18(\mathrm{i})(1982)$.

14. For a discussion of the relevant provisions, see infra notes 99-231 and accompanying text. 
This article describes the UIT in part $I$, offering insight into the mechamics and participants associated with this investment vehicle. To facilitate a better understanding of the UIT, part II analyzes the trust's history, and part III discusses the key provisions of the Securities Act of 1933 (the 1933 Act) ${ }^{15}$ and the 1940 Act that apply to the UIT, with particular emphasis on the registration and disclosure provisions. Finally, to sharpen the distinction between UITs and other fixed portfoho investment vehicles, part IV coinpares UITs with other investment vehicles that have soine fixed portfoho attributes. ${ }^{16}$

\section{The Mechanics of and Participants Associated with Unit INVESTMENT TRUSTS}

The trust indenture, under which a UIT inust be organized, governs the administration of the trust and the activities of those associated with it: the trustee, the depositor and the evaluator. The trust indenture also provides for the termination of the trust and the distribution of its assets. Many indentures stipulate that the trust will terminate after twenty years, although some trusts have a shorter duration and others exist for as many as fifty years. The 1940 Act, section 26 in particular, governs certain aspects of the indenture and, in so doing, controls the identity and activities of a UIT's trustee. ${ }^{17}$

The trust indenture 1.ypically does not govern the underwriting of the trust. Instead, a separate agreement governs the distribution of the trust. UIT underwritings generally are not conducted like the "best efforts" underwriting of a mutual fund. Rather, each underwriter of a UIT becomes the owner of a specific number of trust units on a certain date. For so risking their capital and performing other activities, the underwriters receive a concession out of the public offering price of the units. The concession is often 3.5 to $3.7 \%$ of the public offering price, depending upon how many units the underwriter has agreed to purchase. The public offering price inclucles the sales charge, which often ranges froin 4

15. 15 U.S.C. $\S \S 77 a-77 b b b b$ (1982).

16. Periodic payment plans and the separate accounts of insurance companies, both of which are organized as, or in connection with, UITs, differ significantly from the traditional UIT and its predecessor, and will not be analyzed.

17. For example, no principal underwriter for, or depositor of, a registered UIT may sell units of the trust unless the trust indenture (1) designates a bank with capital of at least $\$ 500,000$ as trustee, (2) requires the trustee to have possession of all of the trust's assets, (3) prohibits the trustec from resigning until a successor trustee has accepted trusteeship, and (4) requires the depositor to mail a notice of substitution to unitholders within five days after the substitution of any security. 15 U.S.C. $\S 80 \mathrm{a}-26$ (1982). The Trust Indenture Act of 1939, id. $\S 77$ aaa, does not govern a UIT's trust indenture because of the exception found in seetion 304 of that act for two or more securities having substantially different rights and privileges, $i d . \S 77 \mathrm{ddd}$. 
to $6 \%$ of the public offering price. The underwriters may earn more than just a concession. If a profit is made on the deposit of securities into the UIT, all underwriters typically share im that profit. Any aggregate loss on the acquisition of securities deposited in the UIT, lowever, is usually borne solely by the sponsor.

The nature of a UIT underwriting lias clianged fundamentally since the days of the fixed trusts. The fixed trusts studied by the Commission in the 1930 s, as discussed in more detail below, ${ }^{18}$ continuously distributed their units. The depositor simply added portfolio securites to the trust and created new umits wlien the demand for them arose. In contrast, most UIT underwritings involve a single offering of fixed size. ${ }^{19}$

In addition to the underwriters, the sponsor, the trustee and the evaluator perform integral functions with respect to the UIT. The sponsor, of course, figures prominently in the life of tlie UIT. It organizes the trust and generally bears all of the accompanying organizational expenses. The sponsor is usually one of the underwriters of the trust. In fact, sometimes all of the underwriters of a trust serve as sponsor or cosponsor. The sponsor earns money from the sales charge tliat constitutes a portion of the sale price of the units, and from the spread between the price at which it sells portfolio securities to the trust and the price it pays for the portfolio securities-the difference between the "offering side" and the "bid side." The sponsor may also receive compensation for providing portfolio supervisory services, because nothing requires only the evaluator to provide tliose services. ${ }^{20}$ The sponsor may even profit froin the use of casli paid to it before the date of settlement for the purcliase of units.

The UIT market is dominated by approximately two dozen sponsors and co-sponsors, many of which are major securities firms. Some sponsors are retailers; they create UITs carrying their own name and sell them to their own customers. Otlier sponsors are wliolesalers; they create trusts that do not carry their name and sell thein primarily to retailers for resale to the retailers' customers.

18. See infra notes $77-78$ and accompanying text.

19. Because the early UITs continuously distributed their shares, they, like mutual funds, had an ongoing relationship with their underwriters. This prompted the Commission to propose that the underwriting contract of a UIT be subject to the same restrictions the Commission drafted for the underwriting contract of a mutual fund. Hearings 3580 , supra note 7 , at 11.

20. The staff of the Commission has agreed that the sponsor's provision of portfolio supervisory services would not cause it to be an "imvestment adviser" of an investment company withm the meaning of section 2(a)(20) of the 1940 Act. Dean Witter Reynolds (pub. avail. May 6, 1983); see 15 U.S.C. § 80a-2(a)(20) (1982). This position is not without significance; section 15(a) of the 1940 Act governs, with specificity, certain aspects of an investment adviser's relationship with an investment coinpany. See id. §80a-15(a). 
The trustee typically plays a ministerial role, with few if any trustee functions; it is more of a custodian and administrator. The trustee, for instance, collects and disburses the interest and dividends due on a trust's portfoho securities. The trustee also provides umitholders with an annual report disclosing such things as interest received, amounts actually distributed, and a list of the securities remaining in the trust as of a certain date. The trustee's report to unitholders, typically provided for as a condition of the trust indenture, is hardly superfluous; unlike inutual funds, UITs are not required by the Cominission to report to shareholders. ${ }^{21}$ For its efforts, the trustee receives an annual fee based on the size of the trust. In addition, the trustee profits from the use of momies it holds on behalf of the UIT in noninterest-bearing accounts for future distributions of interest or principal. Three or four major banks serve as trustee to most UITs, but some UITs ennploy a subsidiary of their sponsor as trustee. ${ }^{22}$

The evaluator of a UIT performs at least one vital trust function. For either a fixed annual fee or a fixed fee per evaluation, the evaluator values the trust's portfolio for purposes of redeinption and the secondary market. The evaluator also inay perform portfolio supervisory services for the UIT; that is, for the purpose of meeting redemptions, the evaluator may designate the portfolio securities to be sold after consideration of a variety of factors such as interest rates, marketability, and inarket value. The evalutor's fee for these supervisory services is often based on the size of the UIT. Nothing in the 1940 Act requires the evaluator to be independent from the sponsor and, indeed, the sponsor or one of its affiliates often serves as evaluator. The evaluator, like the trustee, is paid by the UIT, not by the sponsor.

\section{The BACKground of The UNIT INVESTMENT TRUST}

Unlike the managed investment coinpany, the UIT originated in the United States-not in Great Britain. ${ }^{23}$ One of the earliest trusts arose in 1924 as the result of a businessinan's desire to increase the public ownership in his coinpany. Because his company's stock was selling at $\$ 400$ per share, the businessinan deposited one share of his coinpany with his bank, requested that the bank act as custodian, and obtained ten bankers'

21. Commission rules require only those UITs that invest substantially all of their shares in one management investment company to provide their shareholders with a report. 17 C.F.R. $\$ 270.30$ d2 (1987).

22. The Kemper Tax-Exempt Insured Income Trust, for instance, uses Investors Fiduciary Trust Company (Investors) as its trustee. Investors is jointly owned by Kemper Financial Services, Inc. and DST Systeins, Inc.

23. The first British UIT appeared in 1931. F. Lewcock, The Fixed Trust Yearbook 1936 , at 2 (1937). 
receipts. He then sold the ten receipts of pro rata participating interests. ${ }^{24}$ The popularity of these trusts, known as "fixed" or "semi-fixed" trusts, grew rapidly, and by 1930 fixed trusts had total assets of nearly $\$ 300$ million. ${ }^{25}$ By the end of 1931 , approximately 100 million fixed trust shares had been sold in the United States and niore than 150 trusts had been organized. ${ }^{26}$

The neteoric rise in fixed trusts, however, was not primarily attributable to the desire of businessnien to increase the public ownership of their coinpanies. Rather, the rapid growth resulted front the public's deinand for cominon stock, the predominant investment of the fixed trusts, and froin the public's distrust of managed investment coinpanies that grew fron the misbehavior of the management of those companies during the 1929 crash. ${ }^{27}$ Fixed trusts capitalized on the public's distrust of managenient by emphasizing the trusts' "fixed" nature: investors got what they saw and could rest assured that no managenient would alter or tinker with their investnients.

Newspaper, magazine, nrail and radio advertising substantially contributed to the large volume of fixed trust shares sold froin 1929 to 1931.28 The affordability of fixed trusts, which generally required a minimum purchase of only five shares-each share usually selling in the range of eight to ten dollars-also probably contributed to their early popularity. 29

Unlike the inanaged investment coinpanies, which were largely created by investnient bankers and broker-dealers, fixed trusts typically were created by individual promoters. ${ }^{30}$ Yet, like the managed investment conpanies, fixed trusts relied on investment bankers and brokerdealers to distribute their shares. By 1931, the great niajority of investment bankers were selling fixed trust shares, and dealer syndicates were regularly organizing to sell such shares. ${ }^{31}$ Two factors priniarily attracted dealers to the distribution of fixed trust shares. First, fixed trust sponsors increased the commission on fixed trust shares to six percent of

24. W. DURST, ANALYSIS AND HANDBOOK OF INVESTMENT TRUSTS 265 (1932).

25. FIXED TRUST REPORT, supra note 8, at 239.

26. W. DURST, supra note 24 , at $265-66$.

27. FiXed Trust RePORT, supra note 8 , at $15 ; 4$ T. Frankel, The Regulation of Money MANAGERS, ch. $29, \S$ A.1, at 162 (1980).

28. FIXED TRUST REPORT, supra note 8 , at 151 . These fixed trusts were advertised in such magazines as Atlantic Monthly, Harper's, Scribner's Magazine and The American Mercury. Id. at 151 n.27.

29. FIXED TRUST REPORT, supra note 8 , at 11 .

30. Id.

31. L. Chamberlain \& W. Hay, Investment and Speculation 162-63 (1931). A national survey in 1931 revealed that $86 \%$ of the investment bankers reached by the surveyors were then selling fixed trust shares. Id. at 163. 
the selling price, much more than the commission on bonds that most small dealers sold. ${ }^{32}$ Second, fixed trust shares were sold without any commitment from either primary distributors or dealers. ${ }^{33}$ Because no firm commitment was required, dealers were able to distribute fixed trust shares without tying up capital.

The popularity of UIT's declined after the $1930 \mathrm{s.}{ }^{34}$ Few if any UITs were actively selling their shares by the outbreak of World War II, and less than 100 trusts existed by the end of the war. ${ }^{35}$ UITs increased in number in the 1950s, but their raison d'être had completely changed. They mostly served as funding vehicles for purchasing interests im either the stock of a single industrial corporation or a specified mutual fund. ${ }^{36}$ Because they issued "periodic payment plan certificates," these UITs were inerely a mechanisin for buying something else on an installment basis. The forty installment plans that did invest in fixed trust shares during the $1930 \mathrm{~s}^{37}$ dechned in importance, and by 1964 over seventy-five percent of the $\$ 2.9$ inillion of active UIT assets were imvested in investment coinpanies other than UITs, most of which were mutual funds. ${ }^{38}$

UITs resembling the old fixed trusts began to reappear in 1961 as an investınent vehicle for municipal bonds. Until the tax laws changed im 1976 to allow mutual funds to pass through moome from municipal bonds on a tax-free basis, UITs offered investors the only tax-exempt way of obtaining a diversified portfoho of nunicipal bonds. ${ }^{39}$ As UITs increased in number and size, their colmection with municipal bonds continued. By the end of 1986 , over ninety percent of the 7900 UIT series invested predommantly im municipal securities. Of the more than $\$ 110$ billion invested in UITs, more than $\$ 91$ billion were im municipal trusts

32. FiXed Trust REPORT, supra note 8, at 17 . .

33. Id. at 17, 146; L. Chamberlain \& W. HAY, supra note 31 , at 163.

34. Securities and Exchange Comm'n, Public Policy Implications of Investment Company Growth, H.R. Rep. No. 2337, 89th Cong., 2d Sess. 38 (1960) [hereinafter Public PolICY IMPLICATIONS].

35. 7 SEC ANN. REP. 8 (1941); 13 SEC ANN. ReP. 110-11 (1947). For a hist of the 56 UITs registered with the Commission as of November 12, 1940, see Investment Company Act Release No. 13 (Nov. 19, 1940).

36. Both UITs that registered in 1954 were organized for the purpose of operating periodic payment plans for the purchase of mutual funds. 20 SEC ANN. REP. 94 (1954). Both UITs that registered in 1955 did so to invest in the stock of a single industrial corporation. 21 SEC ANN. REP. 97 (1955).

37. FIXED TRUST REPORT, supra note 8, at 160; see also W. DURST, supra note 24, at 296-99.

38. 30 SEC ANN. REP. 111 (1964). In 1964, 107 active UITs existed; 54 were periodic-payment UITs, with $\$ 2.4$ billion in assets, wlule the remaining 53 had $\$ 450$ million in assets. Id.

39. 4 T. FrankeI, supra note 27, ch. 16, $\S 16$, at 314. The passage of the Tax Reform Act of 1976, Pub. L. No. 94-455, 90 Stat. 229, made clear that the pass-through tax exemption treatment of investment companies organized as trusts and investing in tax-exeinpt securities also extended to investment companies organized as corporations. 
alone. ${ }^{40}$ While the modern UITs that invested in municipal bonds initially resurfaced in 1961, the first corporate bond and preferred stock UITs did not appear until 1972, and the first government securities UITs were not offered until $1978 .{ }^{41}$

\section{A. The Early Fixed Trusts.}

Like their modern counterparts, the early fixed trnsts were conceptually simple. An organizer acquired a diversified portfolio of securities, deposited them with a trustee, and issued a certain number of participating units or trust certificates against the deposited securities. The price of the units sold was based on the current market value of the unit, and the securities placed in the trust were selected either by the organizer itself or by one of the various professional statistical organizations. ${ }^{42}$ While the early trusts were set up with termination dates ranging from two to ninety-nine years, most trusts terminated twenty years from inception..$^{43}$ At maturity, the securities of the trust were liquidated and the proceeds, along with any other trust assets, were proportionately distributed to shareholders.

The early fixed trusts varied froin each other in several key respects. Trusts known as "distributive" trusts sold all stock dividends and rights received from their portfoho securities and disbursed the proceeds to unitholders. Other trusts retained those rights in their portfolios; they were known as "accunulative" trusts. The popularity of these two types of trusts varied with one's view of the stock niarket and the economy; accumulative trusts were popular in "bear" markets whereas distributive trusts were popular in "bull" markets. ${ }^{44}$ Soine trusts featured reserve funds, in which a certain amount of trust imcome was retained each year, while other trusts distributed all income received. ${ }^{45}$ The reserve fund of a trust allowed it to take up stock subscription rights in its portfolio securities, to add inore shares of certam portfohio conipamies to the trust, or to maintain a certain fixed dividend rate. Over time, the reserve fund tended to build up the rate of income of the trust, through the reinvestinent of such reserves in interest-bearing assets. ${ }^{46}$ During periods of prosperity, however, the reserve proved disadvantageous because the yield on its reinvestnents could be less than the appreciation on

40. INVESTMENT Co. INST., supra note 6.

41. Wiesenberger INv. Cos. SERV., InVestMent Companies 1980, at 577, 580 (1980).

42. M. WILliams, supra note 8 , at $34,70$.

43. W. DURST, supra note 24, at 269.

44. Id. at 272.

45. M. Williams, supra note 8, at 72. Some organizers created the reserve fund by depositing cash along with stock at the inception of the trust. Id.

46. Id. at 34-35. 
securities. ${ }^{47}$

\section{B. The Depositor.}

The depositor performed a number of functions and enjoyed a variety of powers with respect to the fixed trusts. It deposited the underlying securities into the trust, specified the tine of sale of portfolio securities, reinvested trust monies, voted the portfolio securities, terminated or extended the trust under certain conditions, and appoimted a successor trustee in the event of removal, resignation, or incapacity. ${ }^{48}$ The depositor had the power to assign all of its rights to another company with the trustee's approval, to call a meeting of shareholders to ascertain their views, and to amend the trust agreeinent-without shareliolder consent-with respect to minor changes. ${ }^{49}$

The depositor received coinpensation from a variety of sources. In fact, soine depositors earned more froin the "hidden charges" associated with fixed trusts than from the publicized sales load.50 The "hidden charges" came from a number of sources. Several of the "hidden charges" were counected to the depositor's sale of portfolio securities to the trust. The depositor bought securities for the trust on the bid side, but sold them to the trust at the offering side. Furthermore, the depositor added a brokerage commission to the price of securities sold to the trust, and, with few exceptions, charged the trust odd-lot brokerage preiniums-even though the clepositor purchased the portfolio securities in round lots. The depositor retained the difference. ${ }^{51}$ The depositor also adjusted the cost of the portfoho shares by rounding thein to a higher fraction of a dollar. ${ }^{52}$

Other "hidden charges" were connected to the sales load. The depositor not only earned the difference between the bid and the asked price on the portfolio securities it sold to the trust; it typically charged a sales load on the same differential and on the differential between the odd-lot and the round-lot brokerage commission as well. ${ }^{53}$ It also charged a sales load on accumulations, which were sums sucli as cash

47. Id. at 51 ; W. Durst, supra note 24 , at 286 . The reserve fund feature lost popularity and was discontinued as a result of rising markets.

48. FIXED TRUST REPORT, supra note 8, at 39-40.

49. Id. With the consent of the trustee and a majority of the shareholders, the depositor could amend the trust with respect to things other than basic aspects of the trust. Id.

50. Id. at 165 .

51. Id. at 149, 166; L. Chamberlain \& W. HaY, supra note 31 , at 137-40.

52. FiXed TRUST RePORT, supra note 8, at 167-68.

53. Id. at 167. The Commission issued a stop order suspending the effectiveness of a registration statement of a fixed trust, because the trust failed to disclose, among other things, the sales load on the bid-offering differential. In re T.I.S. Management Corp., 3 S.E.C. 174 (1938). 
dividends that had accrued on the portfolio securities since the previous distribution date, which were added to the offering price and paid by the investor as equalization payments (the pro rata amount of the accumulation that had accrued since the previous distribution date). Because these accumulations were disbursed to the investor at the next distribution, charging a sales load on accumulations amounted to cliarging the investor for the advance of his inoney. ${ }^{54}$ The depositor also failed to reduce the sales load as the termination date of a trust approached, and since part of the sales load typically coinpensated the trustee for its services rendered during the entire existence of the trust, the depositor inade a greater profit on secondary inarket sales as a trust neared termination because of the fees it would not have to pay the trustee. ${ }^{55}$ When a trust preinaturely terminated, the depositor also retained sales loads, which again coinpensated the trustee..$^{56}$

The depositor inade inoney on the trust through inore than just the workings of the sales load and the deposit of the portfolio securities. The depositor also often paid itself the interest earned on any funds of the trust and soinetimes paid itself a manageinent fee froin trust assets. ${ }^{57}$ As witl portfolio securities, the depositor often rounded up to a higher fraction the offering price of the trust's shares. ${ }^{58}$ When the trustee sold trust property such as stock dividends to inake distributions, it soinetimes sold the property to the depositor at less than the best price obtainable, allowing the depositor to resell it for an immediate profit. ${ }^{59}$ Additionally, when investors sought to hquidate their investinents by converting their trust units into the underlying property owned by the trust, the depositor often charged a conversion fee. ${ }^{60}$ With other investors seeking to liquidate, the depositor miglit drop its bid price below the liquidating value and then liquidate the shares at a profit. 61

No discussion of depositor coinpensation would be coinplete without soine inention of excliange fees. Trust sponsors often inade a series of offers to excliange old trust shares for shares of newly created fixed

54. FIXed TRUST REPORT, supra note 8, at 166-67.

55. Id. at 173-74.

56. Id. at 174 .

57. Id. at 172-73. Some trusts charged the unitholders $10 \%$ of current income on an annual basis. L. ChamberLa1N \& W. HAY, supra note 31 , at 139. The fact that some depositors charged their trust a management fee may explain why the definition of a UIT, found in section $4(2), 15$ U.S.C. $\$ 77(d)(5)$ (1982), does not define a UIT as an investment company without an investment adviser.

58. FIXed TRUST RePort, supra note 8, at 167-68.

59. Id. at 175-77.

60. Id. at $180,193$.

61. Id. at 177. 
trusts and, subsequently, for shares of mutual funds. ${ }^{62}$ These exchanges were accompanied by additional sales loads. Pressured by the threat of their trust being terminated, by warnings of the loss of money if an exchange were not made, and by promises of benefit if an exchange were made, investors were often persuaded to switch from one trust to another. ${ }^{63}$ Because an investor's assets were so depleted by the successive sales loads that accompanied each exchange, however, a depositor usually could induce only two exchanges. ${ }^{64}$ Campaigns to induce exchanges often began shortly after shares of the fixed trust were sold. ${ }^{65}$ Exchanges were so important that when depositors sold control of their busmesses to someone else, the price depended on the purchasers' success im persuading investors to exchange out of their trust units. ${ }^{66}$ Addimg imsult to injury, investors were not infrequently led to believe that depositors made exchanges without profit. ${ }^{67}$

Many depositors' lack of stability created hquidity problems for trust investors. Depositors often lacked significant assets, and they frequently assigned interests in their businesses to others. Repeated transfers were not unusual and vere typically accompanied by diminution and depletion of the depositors' assets. The depositors were generally organized as corporations; at some point, the repeated transfers of interest transformed the corporations into mere shells. ${ }^{68}$ This often resulted in no one standing ready to repurchase investors' fixed trust shares. ${ }^{69}$ "Orphan trusts," a problem specifically addressed by the 1940 Act, thus arose.

\section{The Trustee.}

While the trustee of a fixed trust generally had rather limited duties, it nonetheless filled two vital roles. It performed a variety of mostly administrative tasks and, of equal importance, lent its prestige and name to the fixed trust enterprise. Advertiseinents for fixed trusts stressed, perhaps more than anything else, that the portfoho of a trust was placed in the custody of a trustee and that investors thus were completely protected. ${ }^{70}$ In fact, one reason for the relatively few fixed trust sponsors was that it became difficult for new trust sponsors to find leading banks
62. Id. at 209.
63. Id. at $230,209$.
64. Id. at 209.
65. Id. at 230.
66. Id.
67. Id. at 211 .
68. Id. at $39,47,206$.
69. Id. at $39,206$.
70. Id. at 73 . 
to act as trustees. ${ }^{71}$

In addition to lrolding legal title to a trust's portfolio, the trustee administered the trust. It created the trust units upon tlie deposit of the portfoho securities by the depositor, received all inconie and distributions on the portfolio securities, credited interest and otlier payments to trust shareholders, and sold portfolio securities, including tlose received througli stock dividends, upon the depositor's direction. The trustee also voted the shares of the portfolio coinpanies as directed by the depositor, ${ }^{72}$ delivered proxies to the depositor, and kept the books and records, maintaining them for inspection..$^{73} \mathrm{~A}$ key power not delegated to the trustee was that of inaking substitutions to the trust. ${ }^{74}$ Soine trustees, however, were given authority to eliminate portfolio securities from a trust. $^{75}$

\section{Financing and Distribution of the Fixed Trust.}

Anotlier aspect of the fixed trust in whicli banks played an integral role lay in the financing of the trust. Banks often financed depositors' purchase of portfolio securities, especially when they liad agreed to serve as trustee of a particular trust. The bank would extend credit to the depositor by advancing it sufficient funds to pay for the portfolio securities delivered to the bank by the brokers selling the portfolio securities. The bank then took the securities as trustee and issued trust certificates against the deposit. The bank thus possessed either the portfolio securities or the trust certificates at all times. When the depositor received a draft from a dealer to pay for trust shares, it then immediately discounted the draft witl the bank so that it could free up its capital. ${ }^{76}$

The bank also served as the fulcrum in the distribution cham of fixed trust securities. Investors typically ordered fixed trust shares from retail dealers who placed orders with wholesale distributors. The orders then generally went to the depositor, who directed a broker to purchase the securities necessary to create a unit and then deposited the portfolio

71. Id. at $34-35$.

72. In 1931, the New York Stock Exchange began requiring trusts that sought to remain on the Exchange's "unobjectionable" list to provide for voting by trust shareholders whose ownership in a fixed trust was sufficiently large to be equivalent to whole shares in the trust's portfolio. Despite this requirement, trust shareholders apparently never exercised this right. Id. at 100-01; see also W. DURST, supra note 24, at 283 (describing voting arrangements).

73. Fixed TRUST REPORT, supra note 8, at 73-74.

74. See id. at $125-26$ (classifying fixed trusts by type of elimination and substitution provisions); cf. id. at 88-89 (recounting testimony of trust company officer about lack of substitution and elmination powers).

75. Id. at $\mathbf{1 2 5}$

76. Id. at 150 . 
securities with the trustee. The trustee issued trust certificates and delivered them to the depositor; the imvestor received his shares after they had gone tlirough the wholesale distributor and the retail dealer. ${ }^{77}$ It is important to note that the distribution of fixed trust shares involved a continuous offering; as nore orders were received, new units of the trust were created. Unlike a conventional offering, in which the pronioter or sponsor could not alter the amount of stock issued after execution of the underwriting agreement, a fixed trust sponsor "could regulate, at will, the quantity of shares issued depending upon the public response."78 UITs typically also involved a contimuous offering, but generally for a different reason-the maintenance of a secondary market in the trust shares.

\section{E. Liquidity of Trust Shares.}

While few of the earliest fixed trust shares sold ever returned to the market, 79 fixed trust purchasers nonetlieless had several alternatives available when liquidating their investments. Some trusts redeemed their shares, eitlier in cash or in kind, and because fixed trusts consisted of units of specified securities, the fixed trust investor was generally able to obtain his proportionate slare of portfolio securities from the trustee at any time. ${ }^{80}$ Of course, mvestors paid for the right to convert, and in most cases a large portion of the conversion charge was pure profit to the trust sponsor. ${ }^{81}$ Many trust sponsors did inaintaim a secondary market for shares issued by their trusts, ${ }^{82}$ although their volume of activity was not large.

Fixed trust investors could liquidate their shares througln inarkets other than those maintained by trust sponsors. Some fixed trust shares traded on stock exchanges, particularly the smaller stock exchanges, ${ }^{83}$ and it was not always necessary to list a fixed trust on a given exchange to trade it on that exchange. ${ }^{84}$ The listing of fixed trust shares that did occur discontinued in 1935 and was accompanied by the delisting of most trusts then listed. At least one industry representative attributed

77. Id. at 148-49.

78. Id. at 146; see also id. at 10; M. WILliams, supra note 8, at 23-24 (Both fixed trusts and open-end management trusts differ from ordinary corporate issuers in the practice of continuously offering their shares.).

79. L. Chamberlain \& W. HaY, supra note 31 , at 143.

80. FiXed TRUST RePORT, supra note 8 , at 9.

81. Id. at 193.

82. W. DuRST, supra note 24, at $269,291$.

83. Id. at 269.

84. FIXED TRUST RePort, supra note 8, at 201. Fixed trusts' shares traded, among other places, on the Chicago Board of Trade, the Chicago Curb Exchange, and the New York Produce Exchange. 
this to the detailed requirements of the Securities Exchange Act of $1934 .{ }^{85}$ In addition to the exchanges, investors could often sell their fixed trust shares im the over-the-counter market. ${ }^{86}$

\section{F. Elimination and Substitution of Portfolio Securities.}

The "fixed" nature of fixed trusts evolved over time. While fixed trusts becaine popular in response to the public's dissatisfaction with managed trusts, their very rigidity necessitated further refinements. As market conditions changed, rigidly fixed trusts were unable to respond to significant market movements because of their "frozen" portfolios. Trust sponsors attempted to resolve the problem of rigidity by creating new trusts with soine power to eliminate or substitute portfoho securities and by persuading trust shareholders to switch, for a sales charge of course, into the newer trusts. ${ }^{87}$

Fixed trusts were created with at least four types of elimination or substitution authority. Some trusts allowed the elimination of securities, but only in instances of merger, consolidation, reorganization, or the sale of all of the portfoho company's property. Other trusts allowed ehimination on the basis of some inechanical test such as a portfolio company's passage of a dividend for several periods. A third type allowed the elimination of portfolio securities generally, within the discretion of the depositor, the trustee, or both, and a fourth type allowed substitutions by the depositor as well as eliminations. ${ }^{88}$

The elimination provisions of fixed trusts often became rather complex. A portfolio company could be eliminated: (1) if its rating was discontinued or fell below a certain level; (2) if it reported average net earnings lower than the net earnings over the immediately preceding three years; (3) if its price ever exceeded its "intrinsic" worth; (4) if the depositor opined that the portfolio company's capital and surplus were endangered; (5) if the trust sharelolders voted to eliminate it; or (6) if its value exceeded some value specified in the trust agreement. ${ }^{89}$

Those engaged in the selling of fixed trusts frequently emphasized the elimination provisions. Fixed trust sponsors einphasized the inportance of the elimination provisions and of the superior nature of their provisions as compared to otliers. ${ }^{90}$ The New York Stock Exchange required members seeking to organize or affiliate with a fixed trust to dis-

85. Id. at 202.

86. Id. at 203-06.

87. Id. at 128; W. DuRST, supra note 24, at 291.

88. FIXED TRUST REPORT, supra note 8 , at 125,129 ; M. Williams, supra note 8 , at 71 .

89. Id. at $126 \mathrm{n} .8$.

90. Id. at 126. 
close their elimination and substitution provisions in their advertisennents if their advertisements included any information usually contained in the trust's offering circular. ${ }^{91}$

Despite their evolution and the inportance placed upon them by the trust sponsors who created thein, elimination provisions proved a mixed blessing. They actually created inany of the large losses sustained by fixed trusts. ${ }^{92}$ In particular, the provision requiring elimination of portfolio coinpanies that had passed a dividend was singled out as forcing elinination at the worst time..$^{93}$

\section{G. Fixed Trust Advertising.}

Fixed trust advertising was often incoinplete or misleading. Many trust sponsors inproperly characterized what their trusts were distributing; thus many trust purchasers did not realize how substantial a part of the returns that they received labeled as "dividends" was merely repayment of the capital they had contributed to the trust. ${ }^{94}$ This problen was especially acute with the first distribution of a trust, when some trust sponsors backdated trust agreenents to inake it appear that the first distribution represented earnings, not a return of capital. ${ }^{95}$ Trust sponsors also failed clearly to distinguish stock dividends froin cash dividends in their advertising. The inore ineticulous fixed trusts, however, did distinguish between their cash cividends and the cash distributed froin the sale of stock dividends. ${ }^{96}$

Hypothetical performance advertisements also deceived investors. Trust sponsors often advertised what their trust would have earned had it been created up to twenty years earlier. This hypothetical performance included the cash and stock dividends, stock rights, and split-ups that the trust would have received during the relevant period, even though soine of the underlying securities would have been eliminated by the trust's elimination provisions. ${ }^{97}$ In 1931, the New York Stock Exchange prohibited its members froin including lypothetical performance in fixed trust offering circulars and required trusts that showed performance in their offering circulars to do so for each year of the trust since inception. ${ }^{98}$

91. W. DURST, supra note 24 , at 419.

92. FIXED TRUST REPORT, supra note 8, at $143-44$.

93. Hearings 3580, supra note 7, at 186 (statement of David Schenker, Chief Counsel, SEC Investment Trust Study).

94. L. Chamberlain \& W. HAY, supra note 31 , at 155.

95. FIXED TRUST REPORT, supra note 8, at 155.

96. L. Chamberlain \& W. HAY, supra note 31 , at 158.

97. FIXED TRUST REPORT, supra note 8, at 153-54.

98. W. DURST, supra note 24 , at 418. 


\section{Unit INVESTMENT Trusts Under the 1933 and 1940 ACTS}

Many of the 1940 Act's provisions are irrelevant to fixed portfolio investment companies such as UITs. Several provisions, however, are particularly relevant to UITs. Unfortunately, as with many statutes, the legislative-and administrative-history is sometimes frustratingly vague. The key UIT provisions under the 1933 Act, fortunately, are more straightforward and circumscribed.

\section{A. Registration and Disclosure Under the Securities Laws.}

UITs, like other mvestment companies, receive special registration and disclosure treatment under the securities laws. Mutual funds and UITs, for instance, may register an indefinite number of shares under their registration statements and then pay for the net shares sold (shares sold less shares redeemed) at the end of the year. Such registration treatment is not accorded non-investment-company issuers under the securities laws. Before this section examines the registration and disclosure provisions of the 1933 and 1940 Acts that specifically affect UITs, however, some background is needed.

A UIT is generally comprised of many series. Each series issued by the trust has a different portfolio, and a purchiaser of units looks ouly to that series for his investment return. Although two series within a trust might be identical except for the fact that their portfolios contain different securities, there is no requirement that series within a trust be identical or even similar; indeed, they often are not. Each series is considered a separate offering under the 1933 Act and must file a separate registration statement that becomes effective under section 8(a) of that act. ${ }^{99}$ Only the trust itself, however-and not each series-need register under the 1940 Act. (In contrast, a single mutual fund may also consist of a number of series that must each be registered under the 1933 Act, but each such series need not be registered pursuant to a separate registration statement under the 1933 Act.) The relatively large growth im the number of UITs and their series, even in comparison to the rapid growth in the size of the mutual fund industry, has led the Cominission to revise substantially the UIT registration process.

1. 1933 Act Registration Provisions. In 1982, the Commission adopted rule $487,{ }^{100}$ granting UITs registration rehef not previously

99. 15 U.S.C. $\S 77 \mathrm{~h}(\mathrm{a})(1982)$.

100. 17 C.F.R. \& 230.487 (1987); see Automatic Effectiveness of Registration Statements Filed by Certain Investment Trusts, Securities Act Release No. 6401, [1982 Transfer Binder] Fed. Sec. L. Rep. (CCH) I 83,210, at 85,059 (May 7, 1982) (announcing adoption of rule 487) [hereinafter Release 6401]. 
granted to any other issuer. The rule, which was originally proposed as rule $475 \mathrm{~b},{ }^{101}$ permits a particular type of 1933 Act registration statement to become effective autoniatically, without affirmative action by the Commission staff. It also permits a registrant to designate the date and time of the registration statement's effectiveness. In proposing the rule, the Commission noted that rule $485^{102}$ permitted posteffective amendinents to 1933 Act registration statements filed by mutual funds and UITs to becoine effective autonatically, without affirmative action by the Commission. ${ }^{103}$ It further noted that, under rule 485(b), certam posteffective amendments, including the annual updating amendments filed to make the financial statements im a registrant's prospectus current pursuant to section 10(a)(3) of the 1933 Act, ${ }^{104}$ may become effective immediately upon filing or on a date chosen by the registrant within twenty days after filing. ${ }^{105}$ While initial registration statements for UIT series could not becoine effective under a rule governing posteffective amendments (section 8(a) of the 1933 Act governs the effectiveness of initial registration statements ${ }^{106}$ and section $8(\mathrm{c})$ governs posteffective amendments ${ }^{107}$ ), the Commission stated its behef that it was appropriate to treat registration statements for subsequent series of a UIT like posteffective anendments because, like annual updating amendments, registration statements for series of a UIT may vary only with respect to the financial information provided about each series. ${ }^{108}$

To be able to use rule 487, a registrant must identify a previous series of the trust for which the Commission or its staff has determined the effective date of the registration statement. The registrant also must represent that the securities deposited in the series being registered do not differ materially in type or quahity from those deposited in the previous series, and that the registration statement for the new series contains no disclosures that differ in any material respect from those of the previous series, except to the extent necessary to identify the specific portfoho securities deposited in, and to provide essential financial information for, the new series. Finally, the registrant must represent that it has complied with rule $460^{109}$ under the 1933 Act relating to the circulation of a pre-

101. Automatic Effectiveness of Registration Statements Filed Under the Securities Act of 1933 by Certain Unit Investment Trusts, Securities Act Release No. 6356, [1981-1982 Transfer Binder] Fed. Sec. L. Rep. (CCH) I] 83,041, at 84,585-86 (Oct. 21, 1981) [hereinafter Release 6356].

102. 17 C.F.R. $\$ 230.485$ (1987).

103. Release 6356 , supra note 101 , at 84,583 .

104. 15 U.S.C. $\$ 77 j(a)(3)$ (1982).

105. Release 6356, supra note 101, at 84,584 .

106. 15 U.S.C. $\S 77 \mathrm{~h}(\mathrm{a})$ (1982).

107. Id. $\S 77 \mathrm{~h}(\mathrm{c})$.

108. Release 6356 , supra note 101 , at 84,584 .

109. 17 C.F.R. $§ 230.460$ (1987). 
liminary prospectus.

In 1985, in conjunction with the proposal of Form N-7 as the integrated registration form for UITs, the Commission proposed to revise rule 487 so that no UIT series could use the rule unless the previous series being relied upon lad been declared effective by the Commission or its staff within the previous two years. ${ }^{110}$ The Commission explained that, as a result of the significantly different proposed registration form, it wanted to review UIT initial registration statements more closely. When it reproposed Form $\mathrm{N}-7$, the Commission outlined possible furtler changes to rule 487 , intended to simplify filings. ${ }^{111}$

With the adoption of rule 487, the Commission establislied a inechanism that enables inany UIT issuers to go to market whenever they clioose, unconstrained by Commission review. Thus, UIT issuers becaine the first issuers to gain the sort of control over the registration process that soine corporate issuers would later gain when rule $415^{112}$ the "shelf-registration" rule-was adopted.

2. 1940 Act Registration Provisions. The provisions of the 1940 Act that deal with the registration of investment coinpany securities under the 1933 Act have evolved over several decades to simplify the registration process for imvestinent companies. Section 24 of the 1940 Act ${ }^{113}$ has been amended twice: first, to permit investment coinpanies to ainend their registration statements to increase the number of shares registered under the $1933 \mathrm{Act}$, and, second, to provide for the retroactive registration of investinent company securities and the indefinite registration of investinent company securities.

The first of these ainendments occurred in 1954 when subsection (e) was added to section 24. Congress recognized that certain investment companies engaged in continuous offerings-unit investinent trusts, faceamount certificate companies, and inutual funds-and that such companies filed new registration stateinents under the 1933 Act each year to ensure the availability of registered shares. ${ }^{114}$ Noting that section 6 of

110. Securities Act Release No. 6580, [1984-1985 Transfer Binder] Fed. Sec. L. Rep. (CCH) \ 83,774 , at 87,453 (May 14, 1985) [hereinafter Release 6580].

111. Form N-7 for Registration of Unit Investment Trusts under the Securities Act of 1933 and the Invesment Company Act of 1940, Securities Act Release No. 6693, [1987 Transfer Binder] Fed. Sec. L. Rep. (CCH) Il 84,109, at 88,562-63 (Mar. 9, 1987) [hereinafter Release 6693].

112. 17 C.F.R. $\$ 230.415$ (1987).

113. 15 U.S.C. $\$ 80 \mathrm{a}-24$ (1982).

114. H.R. REP. No. 1542, 83d Cong., 2d Sess. 16, 30, reprinted in 1954 U.S. CODE CoNG. \& ADMIN. NEws 2973, 2989, 3003. The legislative history gave no clue as to why UITs were then considered engaged in continuous offerings, that is, whether they were constantly creating new units like the old fixed trusts or were merely engaged in secondary market activities. 
the 1933 Act $^{115}$ provides for the registration of securities through a registration statement but does not provide for registering additional securities through an amendment to the registration statement, Congress added subsection (e) to permit those investment companies to increase the number of shares registered under the 1933 Act by amending their existing registration statement. While the legislative history of this subsection contemplated that an mvestment coinpany could aniend its registration statement at intervals of approximately one year, ${ }^{116}$ the language of section 24(e) permits an investment company to aniend its registration statement anytime after the effective date of the registration statement.

More than twenty years later, in 1977, the Commission proposed and adopted rule $24 \mathrm{e}-2,117$ making the use of section 24(e) significantly less expensive and thus more attractive. By permittimg imvestment companies registering additional securities under that subsection to adjust their registration fees for the securities previously repurchased or redeemed, the Commission recognized that an issuer (and its shareholders) that continuously repurchases or redeems and then resells its shares could pay "inordinately" high registration fees and thus be unfairly burdened by the registration process. ${ }^{118}$ Yet, as proposed, rule $24 \mathrm{e}-2$ offered no relief to UITs. ${ }^{119}$ Several commentators asserted that UITs should be able to utilize the rule, and the Commission agreed, noting that the registration relief of section 24(e) itself extended to UITs as well as mutual funds. ${ }^{120}$ The Commission thus adopted the rule on a basis that made it

115. 15 U.S.C. $\S 77 f(1982)$. Section $6(b)$ of the 1933 Act requires a registrant, at the time it files a registration statement, to pay the Commission a fee of one-fiftieth of one per centum of the maximum aggregate price at which such shares are proposed to be offered. Id. $\S 77 \mathrm{f}(\mathrm{b})$.

116. H.R. REP. No. 1542, supra note 114, at 30, reprinted in 1954 U.S. CODE CONG. \& ADMIN. NEws at 3003.

117. 17 C.F.R. $\$ 270.24 \mathrm{e}-2$ (1987).

118. Computation of Filing Fee for Securities Registered by Open-End Management Companies, Investment Company Act Release No. 9677, [1976-1977 Transfer Binder] Fed. Sec. L. Rep. (CCH) | 81,010 , at 87,670 (Mar. 15, 1977) (proposing rule 24e-2) [hereimafter Release 9677]. "Inordinately high" fees could result because such fees were based on the total anount of securities being registered regardless of whether the securities replaced securities that had been repurchased or redeemed. The Commission reached this conclusion because of its consistent position that, "absent an available exemption, all securities offered or sold by an issuer are subject to the registration requirements of the 1933 Act, notwithstanding the fact that such securities may have been redeemed or repurchased by the issuer subsequent to their earlier sale by the issuer pursuant to a registration statement." Id. The Commission reiterated this position when it adopted rule $24 \mathrm{e}-2$ and reproposed Form N-7. Computation of Filing Fee for Securities Registered by Open-End Investment Companies and Unit Investment Trusts, Investment Company Act Release No. 9819, [1977-1978 Transfer Binder] Fed. Sec. L. Rep. (CCH) II 81,210, at 88,213 (June 16, 1977) [hereinafter Release 9819]; Release 6693, supra note 111 , at 88,554 n.2.

119. As proposed, rule $24 \mathrm{e}-2$ gave registration-fee relief only to open-end management investment companies.

120. Release 9819 , supra note 118 , at 88,213 . 
available to UITs.

Interestingly, one year earher the Commission had proposed and adopted another type of registration relief for various types of investinent companies, including UITs. Rule 24f-2 implemented section 24(f) of the 1940 Act, ${ }^{121}$ which was added to the 1940 Act by the Investinent Company Amendinents Act of 1970. ${ }^{122}$ That section authorized the Commission to adopt rules allowing certain types of investinent companies to register an indefinite number of securities. Section 24(f) and rule $24 \mathrm{f}-2$ thus accommodate the unique character of investinent coinpanies issuing redeenable securities that, with the exception of "certain unit investinent trusts" 123 continually offer their sliares for sale and thus liave difficulty prospectively determining how many securities to register. Rule $24 \mathrm{f}-2$ permits an eligible investinent company to elect to register an indefinite number of securities and then to complete its registration process by filing an annual notice setting fortl the number of shares sold, accoinpanied by the fee owed on such securities. Like rule $24 \mathrm{e}-2$, rule $24 \mathrm{f}-2$ contains a provision allowing registrants to pay 1933 Act registration fees only on net securities sold during the last fiscal year. ${ }^{124}$

In addition to permitting UITs to ainend their registration statements to register additional securities, to pay for sucli securities on a "net" basis, and to register sliares on an imdefinite basis, the Commission permits UITs to register securities retroactively. The Commission received authority to permit retroactive registration in 1970, when section 24(f) was added to the 1940 Act; in 1971 the Commission adopted rule $24 \mathrm{f}-1^{125}$ to impleinent sucl autliority. ${ }^{126}$ Rule $24 \mathrm{f}-1$ allows the retroactive registration of securities unregistered for no more tlian six inonths if

121. 17 C.F.R. $\$ 270.24 f-2$ (1987); see Notice for Public Comment of Proposed Rule 24f-2 Under the Investment Company Act of 1940 and of a Proposed Amendment to Rule 24f-1 Under the Investment Company Act of 1940, Investment Company Act Release No. 9347, [1976-1977 Transfer Binder] Fed. Sec. L. Rep. (CCH) If 80,636, at 86,608 (July 8, 1976) [hereinafter Release 9347].

122. Pub. L. No. 91-547, 84 Stat. 1413, 1424 (1970). Section 24(f) also permits a mutual fund or a UIT to register retroactively securities sold in excess of the number of securities included in an effective registration statement of any such company, in accordance with such rules as the Commission adopts. See infra notes 125-27 and accompanying text.

123. Registration of an Indefinite Number of Investment Company Securities, Investment Company Act Release No. 13,274, [1982-1983 Transfer Binder] Fed. Sec. L. Rep. (CCH) \ 83,355, at 85,964 (May 26, 1983) (proposing revisions to rule 24f-2). The Commission did not describe those UITs not normally offering their shares for sale on a continuous basis, but it probably referred to those UITs for which sponsors were not maintaining a sccondary market.

124. 17 C.F.R. $\$ 270.24 f-2$ (c) (1987). This provision is only available to a registrant who files the required annual notice within two months after the end of its fiscal year.

125. Id. $\S 270.24 \mathrm{f}-1$.

126. Adoption of Rule $24 \mathrm{f}-1$ Under the Investment Company Act, Amended, Investment Company Act Release No. 6805, [1971-1972 Transfer Binder] Fed. Sec. L. Rep. (CCH) ๆ 78,374, at 80,850 (Nov. 5, 1971). 
a filing fee three times the normal fee is paid and a current prospectus was delivered to persons who purchased the unregistered securities. ${ }^{127}$

In 1987 the Commission proposed a registration fee rule to refiect more closely the business practices of UITs. Proposed rule $24 \mathrm{f}-3^{128}$ recognizes that most UITs are created through a one-time deposit of specified securities in a trust, agamst which a fixed, definite number of trust units are issued. Because of the relatively fixed nature of a UIT, only resales and repurchases in the secondary market create the need for a UIT to rely on the indefinite registration provisions of rule 24f-2. Proposed rule 24f-3 adjusts the fee payment provisions of the securities laws to the sales activity of UITs by requiring them to register a definite number of securities when they conduct their imtial public offermgs and by permitting them to register an indefinite number of shares, without paying additional registration fees, for their secondary market resales. Unlike a mutual fund, which generally issues new shares on a continuous basis and thus may never know how many shares it will issue over a given period, a UIT generally does not contmuously issue new shares. Because of a UIT's finite nature, if a UIT sponsor resold the same number of shares it repurcliased in a year, it would owe no additional registration fees under rule $24 \mathrm{f}-2$. Rule $24 \mathrm{f}-2$ merely requires a UIT to pay registration fees, which are often small, for each year in which resales exceed repurchases. Proposed rule 24f-3 would eliminate this registration fee on secondary market imbalances (where secondary market resales exceed repurchases) but require UIT sponsors, like other registrants offering a fixed number of shares, to pay their registration fees at a date closer to the effective date of their registration statement.

If proposed rule 24f-3 is adopted, section 24(e) should again become more important. If a UIT is required to register a definite amount of securities for its imitial offermg, it could use section 24(e) to annend its registration statement to register additional securities. Of course, the proceeds from any new securities issued would have to be imvested in the same sorts of portfolio securities already owned; then the UIT would still fit within that part of the defimition of a UIT requiring it to consist of "specified securities."

3. UIT Registration Forms. Like other issuers, investment companies must register the securities they offer under the 1933 Act. Unlike

127. 17 C.F.R. $\$ 270.24 f-1$ (a), (c) (1987). The six-month and treble-fee provisions implement the specific language of section $24(f)$ of the 1940 Act.

128. Registration of an Indefinite INumber of Securities by Unit Investment Trusts for Purposes of Secondary Market Shares, Investment Company Act Release No. 15,611, [1987 Transfer Binder] Fed. Sec. L. Rep. (CCH) ๆ 84,108, at 88,548 (Mar. 9, 1987). 
other issuers, however, investinent coinpanies inust register themselves under the 1940 Act as well. While this double registration burden has been somewhat mitigated for most investment companies through the adoption of registration forms that integrate the filing requirenients of both acts into one form, UITs are the only major type of investment company for which an integrated registration form has not yet been adopted. UITs fulfill their 1933 Act requirements by filing on Form S$6^{129}$ and their 1940 Act requireinents by filing on Form N-8B-2. ${ }^{130}$ Both of these forms were adopted in 1942,131 and neither has been substantially revised since then. While these forms do require disclosure of useful information, they nonetheless are significantly out of date in that many matters that are material to prospective purchasers are not specifically required by the forms. Conversely, other items of disclosure mandated by those forms, such as the trust sponsor's financial statenients, ${ }^{132}$ are no longer required as a matter of staff policy and no longer provided as a niatter of industry practice.

In 1985, the Commission proposed integration of the registration requirements for UITs. Patterned after Form N-1A, the revised registration form for mutual funds, proposed Form N-7133 consisted of three parts: a simplified prospectus, a Statement of Additional Information (SAI), and other information required only in the registration statement. ${ }^{134}$ Like the mutual fund SAI, the SAI for UITs would have required a inore detailed discussion of matters not required in the prospectus but of possible interest to investors, and it would have been available to prospective mvestors upon request froin the sponsor without charge. Proposed Form N-7 also would have required inclusion of the financial statements of certani third parties that guaranteed the payment of imterest or primcipal of a UIT's portfoho securities. The Commission explanied this proposed requirement by noting the increasing use of these

129. 17 C.F.R. $\S 239.16$.

130. Id. $\$ 274.12$ (1987).

131. Form S-6 was adopted on December 18, 1942. Securities Act Release No. 2887, 7 Fed. Reg. 10,653 (1942). Form N-8B-2 was adopted on January 9, 1942. Investment Company Act Release No. 292, 7 Fed. Reg. 187 (1942).

132. Perplexingly, the Commission continues occasionally to grant confidential treatment to trust sponsors' financial statements under section 45 of the 1940 Act, 15 U.S.C. $\S 80 \mathrm{a}-44$ (1982), although the staff no longer requires them to be filed. See, e.g., Sears Corporate Investment Trust, Investment Company Act Release Nos. 14,543 (May 29, 1985) (notice) \& 14,593 (June 21, 1985) (order); Municipal Investors Trust of America, Series 1 and Subsequent Series, Investment Company Act Release Nos. 14,893, 51 Fed. Reg. 1889 (Jan. 9, 1986) (notice) \& 14,931 (Feb. 5, 1986) (order).

133. Release 6580 , supra note 110 , at 87,453 .

134. Part $C$ of proposed Form N-7, which would have contained the other information required only in the registration statement, was analogous to part II of the registration statements used by noninvestment-company issuers. 
third-party guarantees and their importance to prospective investors. ${ }^{135}$ Finally, the Commission published draft staff guidelines to assist registrants in preparing Form N-7-the first guidelines for UITs ever published. For the inost part the guidelines codified existing disclosure policies.

Proposed Form N-7 generated considerable controversy. Although commentators lauded the Commission for its initiative in integrating the 1933 and 1940 Acts' registration forms and codifying the disclosure practices that had developed over the years, they asserted that the Commission had not sufficiently recluced the amount of required disclosure, that the disclosures in the SAI would be largely repetitive of those in the prospectus, and that the Coinmission should not require UIT registration statements to include the financial statements of third-party guarantors because of the potential hability that UIT issuers could incur under section 11 of the 1933 Act. ${ }^{136}$

The Commission reproposed Form N-7 in 1987, partly because of the siguificant revisions it had made to the form and partly because of an industry request, made after the original proposal of Form N-7, that would substantially affect a UIT's own-as opposed to a third party'sfinancial statements. 137 In 1986, the imdustry requested a relaxation of the requirement that a UIT maintain current audited financial statements in its prospectus. A UIT must maintain a current prospectus so that its sponsor-depositor, which is defined as an "issuer" in section 2(4) of the 1933 Act, ${ }^{138}$ may offer units in the secondary niarket. UIT sponsors asserted that, because of the passive and fixed nature of UITs, the costs of providing annual audited financial statenients outweighed the benefits to investors. In reproposed Form N-7, the Commission agreed to relax the requirenient for audited financial statenients in those instances where they did not seen necessary.

Reproposed Form N-7 contained changes in addition to the relaxation of the audited financial statements requirenent for UITs. Responding to the criticism of the proposed SAI, the Commission abandoned the SAI and returned to the two-part format, requiring only the prospectus and other information required in the registration statement. The Continission also continued to refine the information required in the registration statement so that a prospectus could be prepared in two parts: one

135. Release 6580 , supra note 110 , at 87,451 .

136. Various categories of persons connected to a registration statement are civilly liable under section 11 of the 1933 Act for material omissions or untrue statements of a material fact. 15 U.S.C. $\S 77 \mathrm{k}(1982)$.

137. Release 6693 , supra note 111 , at $88,554-55$.

138. 15 U.S.C. $\S 77 \mathrm{~b}(4)$ (1982). 
part would contain information specific to the series being registered under the 1933 Act and the other part would contain general information about the sponsor and the trust that could be used by other series of the trust. ${ }^{139}$ The Commission also proposed to enlarge the third-party financial statements requirement. Noting that many UITs were now obtaining insurance guaranteeing the payment of portfolio securities' principal or interest, and that the insurance was functionally similar to a guarantee, the Commission proposed to require UITs to include the financial statements of all third parties providing a credit enhancement of a certain amount. The Commission explained that the third-party enhancement might be the critical factor in an investment decision. The Commission added that noninvestment companies were already required to include such financial statements by the Commission's accounting regulations so that investors could assess the ability of a third-party credit enhancer to meet its commitment in the event of default by an issuer. ${ }^{140}$

As with the original proposal of Form N-7, reproposed Form N-7 created considerable controversy. Commentators requested that the Commission revise the specific conditions of the unaudited financial statements requirement, and they assailed the Commission for adhering to-and expanding - the requirements for third-party financial statements. Specifically, commentators asserted that the Commission's expanded requirement for third-party financial statements would cause trust sponsors to cease offering UITs with such credit enhancements. They also offered a variety of technical suggestions for revision. ${ }^{141}$ Adopting this integrated registration form remains a priority for the Commission.

4. UIT Advertising. The rules affecting UIT advertising are virtually identical to those affecting all investment company advertising; this section thus addresses investment company advertising generically. Rules 134 and 482 under the 1933 Act $^{142}$ play an integral role in invest-

139. This refinement, which is similar to the way in which some trust sponsors already assemble their prospectuses, offers several benefits. First, to the extent that the generic portion of the prospectus is truly generic, that part of the prospectus could be used again for future series of the UIT. Second, as long as the generic part of the prospectus remains accurate, the sponsor need not revise it for resales in the secondary market, which, as noted earlier, must be made pursuant to a current prospectus.

140. Release 6693, supra note 111, at 88,559-60; see also 17 C.F.R. $\$ 210.3-10$ (1987) (rule 3-10 of regulation S-X); Securities Act Release No. 33-6359, 46 Fed. Reg. 56,171 (1981) (adopting revisions to regulation $\mathrm{S}-\mathrm{X}$ ).

141. The comment letters discussing reproposed Form $\mathrm{N}-7$ are available for public inspection and copying in the Commission's Public Reference Room, 450 Fifth Street, N.W., Washington, D.C. 20549. File No. S7-9-87.

142. 17 C.F.R. $\$ \S 230.134,230.482$ (1987). 
ment company advertising, while rules $135 a$ and $156^{143}$ play a secondary role.

Until 1979, investment company registrants were subject to the same constraints as other issuers under the 1933 Act, which, with certain exceptions, limits public communications offering securities to statutory prospectuses. The "tombstone rule," rule 134, is one exception to the 1933 Act's general proscription; it allows issuers to announce the existence of their public offering and the availability of a prospectus without triggering the definition of "prospectus" found in section $2(10)$ of the 1933 Act. ${ }^{144}$ The rule contains special provisions for investment companies and, among other things, allows an investment company to provide a general description of itself and include an attention-getting headline. ${ }^{145}$ The use of any performance figure, however, is specifically prohibited.146

Rule $482^{147}$ is the other major exception to the general prohibition on any communications other than the statutory prospectus. Adopted in 1979,148 this rule permits an investment company to include more information than allowed under the tombstone rule. ${ }^{149}$ It does not limit the contents of advertisements provided that the substance of any information in an ad is contained in the statutory prospectus and the ad states where a statutory prospectus can be obtained and advises the investor to read it before investing. Rule 482 thus allows a UIT to advertise any performance figure as long as its statutory prospectus contains a discussion of the type of performance figure advertised. ${ }^{50}$

Rule 156 replaced the Commission's Statenient of Policy, whicli was a detailed statement of the staff's views of sales literature. The rule governs the sales literature- the material that accompanies or follows a statutory prospectus--of investment companies. The rule states the requirement of the federal securities laws that sales literature not be mis-

143. Id. $\S \S 230.135 \mathrm{a}, 230.156$.

144. 15 U.S.C. $\$ 77 \mathrm{~b}(10)(1982)$.

145. 17 C.F.R. $§ 134(a)(3)(i i i)$ (1987); see also id. $\S 134$ (a)(13) (communication may include descriptions of corporations and their products and services as long as description does not relate directly to desirability of purchasing securities of a registered investment company).

146. Id. $\S 230.134$ (a)(3)(iii).

147. Id. $\S 230.482$.

148. Advertising by Investment Companies, Investment Company Act Release No. 10,852, [1979 Transfer Binder] Fed. Sec. L. Rep. (CCH) I 82,198, at 82,254 (Aug. 31, 1979).

149. Rule 482 was adopted under section 10(b) of the 1933 Act, 15 U.S.C. $\$ 77 j(b)$ (1982), which authorizes the Commission to permit prospectuses that omit in part or summarize the information in the statutory prospectus. Ads falling under rule 482 are thus known as "omitting prospectus" ads and carry prospectus liability under section 12 of the 1933 Act, id. $\S 771$.

150. Mutual funds and insurance company separate accounts offering variable annuity contracts, however, are restricted in the types and presentation of performance figures they may advertise. See Advertising by Investment Companies, Securities Act Release No. 6753, [Transfer Binder] Fed. Sec. L. Rep. (CCH) If 84,217, at 88,990-99 (Feb. 2, 1988) [hereinafter Release 6753]. 
leading, and it provides general guidance on some factors that could make sales hiterature misleading. ${ }^{151}$ Rule $135 \mathrm{a},{ }^{152}$ however, allows investment companies to use generic ads containing only explanatory language as long as they mention no mvestment company or its securities by name.

5. Secondary Market Prospectus. As noted earher, a UIT sponsor is considered an issuer of trust umits under section 2(4) of the 1933 Act. While secondary market sales are usually not subject to the 1933 Act once the offering has "come to rest," the courts and the Commission have consistently taken the position that all securities offered or sold by an issuer, unless otherwise exempt, are subject to the 1933 Act, notwithstanding the fact that the securities may have been previously sold pursuant to a registration statement. ${ }^{153}$ A UIT sponsor therefore must maintain a current prospectus if it creates a secondary market in trust units.

The maintenance of a secondary market by a UIT sponsor creates legal obligations for others. As long as the sponsor offers umits for sale, any dealer $m$ units of that trust must also dehiver a prospectus because section 24(d) of the 1940 Act $^{154}$ eliminates the dealer's exception provided by section 4(3) of the 1933 Act. ${ }^{155}$ Section 24(d) was amended in 1954 to eliminate the dealer's exception with respect to securities issued by mutual funds and UITs, on the basis that securities continuously offered to the public by an issuer justified a requirement that all dealers be compelled to use the statutory prospectus. ${ }^{156}$ A significant "third market"-a secondary market maintained by persons other than the sponsors and underwriters of UITs-has arisen in the last two years. Dealers

151. Mutual Fund Sales Literature Interpretative Rule, Investment Company Act Release No. 10,915, [1979-1980 Transfer Binder] Fed. Sec. L. Rep. (CCH) I 82,337, at 82,432 (Nov. 7, 1979). Newly adopted rule $34 \mathrm{~b}-1$, which affects only the sales literature of mutual funds and insurance company separate accounts offering variable annuity contracts, requires investment companies that advertise performance figures in their sales literature to include certain uniformly computed performance figures in addition to any nonstandardized figures used. See Release 6753, supra note 150, at 88,999 .

152. 17 C.F.R. $\S 230.135 a$ (1987).

153. See, e.g., SEC v. Stanwood Oil Corp., 516 F. Supp. 1181, 1184 (W.D. Pa. 1981); First MultiFund for Daily Income, Inc. v. United States, 602 F.2d 332, 335-36 (Ct. Cl. 1979), cert. denied, 445 U.S. 916 (1980); Release 9677, supra note 118, at 87,670; Release 6693, supra note 111, at 88,554 n.2.

154. 15 U.S.C. $\$ 80 \mathrm{a}-24$ (d) (1982).

155. Id. $\$ 77 \mathrm{~d}(3)$. Section $4(3)$ excepts dealers, under certain circumstances, from the prospectus delivery requirements of section 5 of the 1933 Act, $i d . \$ 77 \mathrm{e}$.

156. H.R. REP. No. 1542, supra note 114, at 29-30, reprinted in 1954 U.S. CoDE CoNG. \& ADMIN. NEwS at 3002-03. 
operating in this market should note the requirement that they deliver prospectuses in these circumstances.

\section{B. Dividend Distributions.}

Section 19 of the 1940 Act $^{157}$ governs the disclosures that must be made when an investment company pays a dividend and the frequency with which an investment company can distribute long-term capital gains.

As originally enacted, section 19 dealt only with the disclosure of investment company dividends. ${ }^{158}$ Iromically, while fixed trusts were found to have madequately disclosed the nature of their distributions, ${ }^{159}$ and while section 19 applies to UITs as well as all otlier mvestment companies, UITs are not subject to the only disclosure rule adopted under section 19. Rule 19a-1, ${ }^{160}$ adopted in $1941,{ }^{161}$ applies only to management investment compamies, altlough the reason for this distmction is unknown. The distinction is not academic, lowever, because the rule requires more disclosure than does section 19 alone. Specifically, the rule requires management investment companies to disclose any payments to shareholders reflecting (1) accumulated, undistributed net profits from the sale of securities or other properties, or (2) paid-m surplus or other

157. 15 U.S.C. $\$ 80 a-19$ (1982).

158. Pub. L. No. 76-768, § 19, 54 Stat. 789, 821 (1940) (applicable to "any registered investment coinpany"), reprinted in LEGISLATIVE History OF THE INVESTMENT COMPANY AND INVESTMENT ADVISERS ACT of 1940, at 37 (1940) [hereinafter LegisLative History]. The Commission's proposed section 19 differed significantly from that ultimately enacted as law. The Commission's proposal to prohibit an investment company froin paying any dividend out of any source other than undistributed net incoine, unless the payment of a dividend from such other source was (1) expressly permitted by the company's charter and (2) accoinpanied by a written statement fully disclosing the source of such dividend and offering the recipient an opportunity to reinvest such dividend in the company without salts load. Hearings 3580 , supra note 7, at 14 . The Coinmission was concerned that the imposition of sales loads by investment companies on the reinvestment of capital distributions would result in gradual depletion of an investor's funds. Id. at 275 (statement of L.M.C. Smith, Associate Counsel, SEC Investment Trust Study). The Commission's proposed section 19 also prohibited investment coinpanies froin paying dividends on a security unless a certain asset coverage existed with respect to any securities senior to that receiving the dividend. $I d$. at 14 . As enacted, section 19 sinply prohibited companies from paying dividends out of any source other than accunnulated undistributed net income or net income for the current or preceeding fiscal year, unless such dividend was accompanied by a written statement adequately disclosing the source of such dividend. LEGISLATIVE HistoriY, supra, at 37.

159. See supra note 94 and accornpanying text.

160. 17 C.F.R. § 270.19a-1 (1987).

161. 6 Fed. Reg. 1113 (adopted on Feb. 25, 1941). Rule 19a-1 was last amended in 1973 to inake certain technical revisions, but nothing was stated as to why it did not apply to UITs. See Techmical Amendments to Rules 2a-1, 2a-2, 7d-1, 19a-1 and 30d-1 under the Investment Company Act of 1940 to Conform in the Rules References ro Certain Sections of the Act as Amended by the Investment Company Act of 1970, Investment Company Release No. 7703, [1972-1973 Transfer Binder] Fed. Sec. L. Rep. (CCH) ๆ 79,248, at 82,743 (Mar. 5, 1973). 
capital, ${ }^{162}$ neither of which must be disclosed by UITs.

In 1970 , section 19 was amended ${ }^{163}$ to govern the frequency with which investment compamies distribute capital gains. Once agam, the legislative and administrative history of this provision raises questions. The Commission was on record seeking an amendment to section 19, primarily because it beheved that fund managers were being pressured into frequent capital gains distributions that disadvantaged shareholders with respect to income tax liability. ${ }^{164}$ While the Commission noted that the mutual funds' trade association had published a guide consistent with the revisions to section 19 that the Commission sought, it also noted that the guide did not bind the trade association's members ${ }^{165}$-and, of course, nonmembers would not even be affected by the guide. Moreover, in adopting and proposing to revise rule $19 \mathrm{~b}-1^{166}$ - the rule implementing amended section 19-the Commission noted that the rule would diminish problems associated with managed funds. For example, the rule would lessen the temptation to "churn" a portfolio to realize capital gams on a frequent and regular basis. ${ }^{167}$ Despite this focus on managed funds, however, rule 19b-1 applies to all registered investment companies, including unmanaged funds such as UITs. ${ }^{168}$

The Commission subsequently amended rule 19b-1 to exempt UITs from the rule's prohibition in five situations where events that created the capital gams were substantially independent from any action by the UIT sponsor or trustee. ${ }^{169}$ In so doing, the Commission articulated a ration-

162. 17 C.F.R. § 270.19a-1(a)(2), (3).

163. Investment Company Amendments Act of 1970, Pub. L. No. 91-547, 84 Stat. 1413, 1422.

164. PUblic Policy Implications, supra note 34, at 194-95.

165. Id. at 194 .

166. 17 C.F.R. $\$ 270.19 \mathrm{~b}-1$ (1987).

167. Adoption of Rule 19b-1 Under the Investment Company Act of 1940 Limiting the Frequency of Distributions of Capital Gains by Registered Investment Comparies, Investment Company Act Release No. 6834. [1971-1972 Transfer Binder] Fed. Sec. L. Rep. (CCH) $\{78416$, at 80,917 (Nov. 23, 1971); Notice of Proposal to Adopt Rule 19b-1 Under the Investment Company Act Limiting the Frequency of Distributions of Capital Gains by Registered Investment Companies, Investment Company Act Release No. 6735, [1971-1972 Transfer Binder] Fed. Sec. L. Rep. (CCH) ף 78,308, at 80,727 (Oct. 1, 1971); Rule Proposal for Unit Investment Trust Start-Up Exemptions and Proposed Revision of Rule Regarding Pricing of Investment Company Shares Generally, Investment Company Act Release No. 10,545, [1979 Transfer Binder] Fed. Sec. L. Rep. (CCH) $\Uparrow 81,911$, at 81,142 (Jan. 8, 1979) [hereinafter Release 10,545].

168. Rule 19b-1 essentially prohibits registered investment companies from making more than one capital gain distribution in any one taxable year. The rule was recently anended to allow registered investment comparies to make an additional distribution of long-term capital gains for the purpose of avoiding a special excise tax. Investment Company Act Release No. 16,094, 52 Fed. Reg. 42,426 (1987).

169. Release 10,545, supra note 139, at 81,142-43; Unit Investment Trust Start-Up Exemptions, Final Rules, Investment Company Act Release No. 10,690, [1979 Transfer Binder] Fed. Sec. L. Rep. (CCH) If 82,074, at 81,778-79 (May 15, 1979) [heremafter Release 10,690]. The five UIT exceptions 
ale for rule 19b-1 that UITs found more convimcing: the rule was also intended to prevent imvestor confusion that might arise if capital gains distributions were commingled with distributions of ordinary income. ${ }^{170}$

\section{Payments to Affiliates, Substitution of Securities, and "Orphan" Trusts.}

Section 26 of the 1940 Act $^{171}$ governs a variety of integral aspects of a UIT, including who may serve as trustee or custodian and how the trustee or custodian must keep custody of trust assets. Three of the section's subprovisions deserve special mention, however, because of the problems they attempted to resolve and the inanner in which these subprovisions changed over time.

As drafted by the Commission, the first subprovision, section $26(a)(2)(C)$, prohibited a trust sponsor or underwriter from using interstate commerce unless the trust's indenture prohibited the trustee from paying the depositor or underwriter, or their affiliates, any expense. ${ }^{172}$ This subprovision attempted unequivocally to eliminate the many expenses paid, over and above the sales load, to the promoters of UITs. By the time of its enactment, lowever, the subprovision had been revised so that the Commission could permit "reasonable" fees to be paid to promoters for bookkeeping and "other administrative services" normally performed by the custodian itself. ${ }^{173}$ Little was said in the legislative history about this modification, although the report of the House Committee on Interstate and Foreign Commerce stated that "except under special circumstances" such fees were not to be paid to either the depositor or underwriter. ${ }^{174}$

Over forty years later, in 1984, the Commission proposed a rule to codify certain rehef it had granted under section $26(\mathrm{a})(2)(\mathrm{C})$. This proposal shed new light on the subject of fees paid to UIT insiders. In proposing rule $26 \mathrm{a}-1,175$ the Commission declared that the purpose of section $26(\mathrm{a})(2)(\mathrm{C})$ was to prohibit the depositor from " 'reaping hidden

from the capital gains distribution restriction are: (1) when an issuer calls a UIT's portfolio security, (2) when a UIT sells a portfolio security to meet redemptions and distributes the excess, (3) when a UIT sells a portfolio security to maintain its qualification as a "regulated investment company" under the Internal Revenue Code, (4) regular distributions and prepayment of principal on portfolio securities, such as, Government National Mortgage Association (GNMA) securities, and (5) sales of portfolio securities to maintain the investment stability of the UIT. Id.

170. Release 10,545 , supra note 167 , at 81,143 .

171. 15 U.S.C. $\$ 80 \mathrm{a}-26$ (1982).

172. Hearings 3580 , supra note $\%$, at 18.

173. 15 U.S.C. $\S 80 \mathrm{a}-26(\mathrm{a})(2)(\mathrm{C})$ (1982).

174. H.R. REP. No. 2639, 76th Cong., 3d Sess. 22 (1940).

175. 17 C.F.R. $§ 270.26 \mathrm{a}-1$ (1987). 
profits' through purported administrative fees."176 Congress had associated "hidden loads" and "hidden charges" with UITs. 177 In its report on fixed trusts, the Commission had delineated many of the "hidden loads" associated with UITs, such as the sales load on the spread between the bid and the offering side, and the sale of portfoho securities to the trust at odd-lot prices although the securities had been obtained at a round-lot price. In its proposal, the Commission completed the distinction between "hidden loads" and "hidden charges" through its discussion of "purported administrative fees." In the release accompanying the proposed rule, the Commission announced its interpretation that section 26 permits a payment from trust assets for administrative fees provided that the fees do not exceed the estimated cost of the services provided.178 That is, the services must be provided at cost. The Commission reiterated its insistence on the "at cost" standard when it adopted rule 26a1.179 The Commission rejected a commentator's suggestion that the rule be modified to permit a "reasonable" profit in any administrative fee, declaring that the 1940 Act and its legislative history "unainbiguously demonstrate" that Congress intended to prohibit persons related to the trust sponsor from using administrative fees to realize "hidden profits." ${ }^{180}$ The Cominission also rejected a suggestion that the rule be revised to permit administrative fees "approximately" equal to the cost of the services provided. ${ }^{181}$

The second subprovision, section 26(a)(3), ${ }^{182}$ addresses the "orphan" trust problem discussed earlier. ${ }^{183}$ The Commission had sought to prohibit the depositor of a trust from resigning or from assigning any of its rights or duties unless the Commission by order allowed sucli action, and to prohibit a trustee from resiguing unless a successor trustee liad been appoimted by a court or the Commission by order liad consented to such resiguation. ${ }^{184}$ Instead of adopting the Commission's proposal, Congress adopted section 26(a)(3), whicl prohibits the trustee from re-

176. Payment of Administrative Fees to the Depositor or Principal Underwriter of a Unit Investment Trust, Investment Company Act Release No. 13,705, [1983-1984 Transfer Binder] Fed. Sec. L. Rep. (CCH) ๆ 83,473, at 86,512 (Jan. 9, 1984) [hereinafter Release 13,705].

177. S. REP. No. 1775, 76th Cong., 3d Sess. 8 (1940). The Commission echoed Congress in these concerns. 10 SEC ANN. REP. 160 (1944). For a discussion of "hidden loads" and "hidden charges," see supra text accompanying notes 50-67.

178. Release 13,705 , supra note 176 , at 86,513 .

179. 17 C.F.R. $\$ 270.26 a-1$ (1987).

180. Investment Company Act Release No. 14,065, [1984 Transfer Binder] Fed. Sec. L. Rep. (CCH) ๆ 83,646, at 86,974 (July 27,1984 ).

181. Id.

182. 15 U.S.C. $\$ 80 \mathrm{a}-26(a)(3)$ (1982).

183. See supra notes $68-69$ and accompanying text.

184. Hearings 3580 , supra note 7 , at 18 . 
signing unless the trust has been completely hiquidated and its proceeds distributed to the security holders of the trust or a successor trustee, meeting the same standards that are required of an initial trustee, has agreed to act as trustee. ${ }^{185}$ Even though the staff of the Commission compared the problem of depositors assigning their depositorship to that of fund managers selling their management contract, ${ }^{186}$ the prohibition against such an assigninent by a trust depositor-for some unexplained reason-was deleted.

The third subprovision, section 26(a)(4), ${ }^{187}$ involves portfoho substitutions. It requires a depositor, within five days after a substitution, to deliver or mail to unitholders a notice of substitution that identifies the securities substituted and eliminated. Although enacted as originally proposed by the Commission, this subprovision was later revisited by the Commission with only partial success. In its 1966 report to Congress entitled the "Public Policy Implications of Investment Company Growth," the Commission recommended an amendment to section 26 to require that substitutions be prohibited unless approved by the Commission under the same standard found im section 6(c) of the 1940 Act. ${ }^{188}$ The report expressed the Commission's concern that a shareholder in a UIT is seldom in a position to judge the merits of the substituted security, and that his only recourse in the event of a substitution would be to redeem his shares and probably lose the large sales load common to most UITs. ${ }^{189}$

Despite the Commission's recommendation, however, this problem received more limited treatment in the 1970 amendments. The Investment Company Amendments Act of 1970 added section 26(b), ${ }^{190}$ which prohibits a depositor or trustee of a trust holding the security of a single issuer to substitute securities without prior approval by the Commission,

185. 15 U.S.C. $\$ 80 \mathrm{a}-26(\mathrm{a})(3)(1982)$.

186. Hearings 3580, supra note \%, at 300 (statement of John H. Hollands, SEC staff attorney). Section 26 contains other, unchanged provisions designed to prevent "orphan" trusts. Section 26(a)(2)(A) allows the trustec, if not otherwise remunerated, to charge the trust from its income, and from the corpus if no income is available, for the expenses provided the trustee in the trust indenture. Section 26(d) allows the Commission to seck liquidation of "orphan" trusts in federal district court.

187. 15 U.S.C. $\S 80 \mathrm{a}-26(\mathrm{a})(4)$ (1982).

188. Public Policy Implications, supra note 34, at 337; see also 15 U.S.C. \& 80a-6(c) (1982). Section 6(c) allows the Commission "conditionally or unconditionally [to] exempt any person, security, or transaction from any [or all of the 1940 Act or the rules] thereunder, if ... such exemption is necessary or appropriate in the public interest and consistent with the protection of mvestors and the purposes fairly intended by the policy and provisions [of the 1940 Act]." Id.

189. The report even mentioned a past Commission position in which the Commission aggressively asserted that the substitution of portfolio shares of a UIT constituted an offer of exchange under section 11 of the 1940 Act and was prohibited unless exempted by the Commission. Public POLICY IMPLICATIONS, supra note 34, at 337.

190. 15 U.S.C. $\$ 80 a-26(b)(1982)$. 
using essentially the same standard as in section 6(c) of the 1940 Act.191 The 1970 Amendments Act thus reflected congressional concern with substitutions in those specialized trusts that invest in only one issuerUITs that generally serve as vehicles for investing im mutual funds. The staff of the Commission has remained concerned about the ability of UITs to substitute securities and, as later discussed, ${ }^{192}$ has asserted that substitution shonld occur only under extraordinary circumstances.

\section{Affiliated Transactions.}

Section 17 of the 1940 Act $^{193}$ coinpreliensively regulates all imvestment companies' affiliated transactions (which, with UITs, are transactions between a UIT and its sponsor or principal underwriter), but the section excepts from its coverage the one type of affiliated transaction most likely to occur with a UIT. More specifically, section 17(a)(1) prohibits an affiliated person of an mvestment company from knowingly selling any security or other property to the company, but section 17 (a)(1)(C) excepts such a transaction from the provisions of section 17 if the sale involves only securities deposited with the trustee of a UIT by the depositor. ${ }^{194}$ Because a UIT is a fixed entity and would rarely purchase or sell securities after it is organized, the exception provided by section 17(a)(1)(C) makes the prohibitions of section 17(a) inapplicable to all but the occasional elimination or substitution in which the UIT depositor intended to purchase the security to be disposed of by the trust. ${ }^{195}$

While the mechamics and background to section 17 were much discussed, ${ }^{196}$ and an additional statutory exception to section $17(a)(1)$ was

191. Investment Company Amendments Act of 1970, Pub. L. No. 91-547, 84 Stat. 1413, 1424 (requiring Commission actions to be "consistent with the protection of investors and the purposes fairly intended by the policy and provisions of this title"); see also 15 U.S.C. $\$ 80 \mathrm{a}-6$ (c) (1982) (same).

192. See infra note 246 and accompanying text.

193. 15 U.S.C. $\$ 80 \mathrm{a}-17$ (1982).

194. Id. $\$ 80 \mathrm{a}-17(\mathrm{a})(1)(\mathrm{C})$. When the sale from the sponsor to the UIT involves some asset in addition to securities, an order exempting such sale under section 17 may be necessary. See Sears Investment Trust, Dual Value Series Six, Investment Company Act Release Nos. 16,058 (Oct. 26, 1987) (notice) \& 16,125 (Nov. 12, 1987) (order).

195. For examples of portfolio eliminations in which a UIT obtained exemptive relief from section 17(a)(2) of the 1940 Act to sell its portfolio securities to its sponsor, see Dean Witter Reynolds, Investment Company Act Release Nos. 15,311, 51 Fed. Reg. 33,681 (Sept. 16, 1986) (noticc) \& 15,356 (Oct. 10, 1986) (order); Paine Webber, Investment Company Act Release Nos. 15,399, 51 Fed. Reg. 41,193 (Nov. 5, 1986) (noticc) \& 15,451 (Dec. 3, 1986) (order).

196. See Hearings 3580, supra note 7, at 256-65 (statement of David Schenker, Chief Counsel, SEC Investment Trust Study); id. at 1055-56 (statement of Arthur H. Bunker, Executive Vice President, Lehman Corporation); S. REP. No. 1775, 76th Cong., 3d Sess. 7 (1940); H.R. REP. No. 2639, 76th Cong., 3d Sess. 17-18 (1940). 
added, ${ }^{197}$ Congress provided no explanation as to why it excepted the affiliated transaction most common with UITs from the coverage of section 17. The Comission's clraft legislation contained this statutory exception to the prohibitions of section 17 , and it was not substantially modified as the law was enacted. ${ }^{198}$ The exception may have resulted from a recognition that most UITs were created through just these sorts of affiliated transactions, and that forcing them to obtain exemptive relief (a transaction subject to section 17(a) is prohibited unless the Commission grants exemptive relief under section 17(b)) at this imceptive stage might irreparably detam them from reaching the market. Alternatively, the exception may have arisen from the behef that disclosure of the various fees a depositor made upon the deposit into the trust could effectively solve the problem. Another possibility is that the Commission's draft legislation contained this exception as a pohtical accommodation to the UIT industry.

\section{E. Size of Investment Companies.}

Section 14 of the 1940 Act ${ }^{199}$ changed as dramatically as any of the provisions in the Commission's draft legislation. As enacted, section 14 required that registered investment companies have a mimimum net worth of $\$ 100,000$ to make a public offering; the Commission's draft legislation contained the same mimimum capital requirement but also would have limited the maximum size of investment compames. UITs, for imstance, would liave been limited in size to $\$ 150,000,000 .{ }^{200}$ David Schenker, Chief Counsel to the Commission's Investment Trust Study, acknowledged that such a limitation presented problems, but he defended the provision because of the possibility of a "run on the company."201 A run on an investment company issumg redeemable securities, he declared, was no different from a run on a bank, and could result in an undesirable effect on the stock market and an illiquid imvestment for investment company shareholders slow to redeem their shares. ${ }^{202}$ Another theory offered for the maximum size limitation was that such a limitation would prevent investment companies from serving

197. See 15 U.S.C. $\$ 80 a-17(a)(1)(B)$; LeGISLATIVE HISTORY, supra note 158 , at 30 .

198. Hearings 3580, supra note 7, at 12; Legislative HistoRY, supra note 158, at 30.

199. 15 U.S.C. $\S 80 \mathrm{a}-14$ (1982).

200. Hearings 3580, supra note 7 , at 10-11. Furthermore, the Commission's draft legislation would have prohibited a person from serving as investment adviser or manager of an investment company if she was already acting in such a capacity with other investment companies whose total assets exceeded certain limitations. Id.

201. Id. at 245-47.

202. Id. at 247 . 
as disguised holding coinpanies. ${ }^{203}$ Representatives of the investinent coinpany industry opposed this limitation, however, ${ }^{204}$ and it was replaced by a provision that authorized the Commission to study and report to Congress on the size of investinent companies and their effect on the securities markets, the concentration of wealth, and the coinpanies in which they invest. ${ }^{205}$

The minimuin size limits of the Conmission's proposed section 14 also received critical scrutimy; however, the suggested $\$ 100,000$ floor was enacted-perhaps because of the staff's concern over "fly-by-night" operators. ${ }^{206}$ Section 14(a)(2), however, excepts an investment company froin the $\$ 100,000$ minimuin capital requirentent if it has previously made a public offering of its securities and had a net worth of at least $\$ 100,000$ at that time. While many UITs organized today niay not be concerned with this low threshold, those organized in series forn as part of a single trust registered under the 1940 Act might be able to rely on the offerings of the other series within the trust, as long as one of the prior series qualified under section 14(a)(2).207

Rule 14a-3208 creates another exception-solely for UITs-to the minimuin capital requirements of the 1940 Act. Premised on the realization that a UIT requires inuch less commitment than a managed investment company, ${ }^{209}$ the rule exempts a UIT from section 14(a) of the 1940 Act if the trust holds at least $\$ 100,000$ of certain portfolio securities ${ }^{210}$ at the commencenient of the offering. The rule also requires, however, that each UIT purchaser receive his pro rata share of the UIT's net worth, plus a refund of all sales charges paid on the purchase of UIT units, if the

203. J. Seligman, The Transformation of Wall Street 227 (1982).

204. Hearings 3580, supra note 7, at 1058; Hearings on H.R. 10,065 Before a Subcomm. of the House Comm. on Interstate and Foreign Commerce, 76th Cong., 3d Sess. 98 (1940) [hereinafter Hearings 10,065].

205. This change has been characterized as among the major concessions made by the Commission in the 1940 Act. J. SELIGMAN, supra note 203, at 228-29.

206. Hearings 10,065, supra note 204, at 116-20.

207. Seetion 14(a)(2) has never formally been interpreted by the staff. Whether it would construe the various discrete series of a UIT to constitute "such counpany" within the meaning of section $14(a)(2)$ is not certain.

208. 17 C.F.R. $\S 270.14 a-3$ (1987).

209. Release 10,545 , supra note 167 , at 81,141 .

210. While the relief granted by rule $14 \mathrm{a}-3$ is available essentially only to UITs investing in certain types of debt obligations, exemptive relief has been given to UITs adhering to the conditions of the rule that imvest in convertible and common stock as well. See, e.g., Prudential-Bache Securities, Unit Investment Trust Exemptions, Investment Company Act Release Nos. 15,622, 52 Fed. Reg. 9228 (Mar. 13, 1987) (notice) \& 15,671 (Apr. 8, 1987) (order); E.F. Hutton \& Company, Investment Counpany Act Release Nos. 14,589 (June 21, 1985) (notice) \& 14,635 (July 16, 1985) (order); E.F. Hutton \& Company and Hutton Telephone Trust First Tax-Free Exchange Series and Subsequent Series, Investınent Company Act Release Nos. 13,514 (Sept. 19, 1983) (notice) \& 13,579 (Oct. 17, 1983) (order). 
net worth of the trust declines to less than $\$ 100,000$ within ninety days after the effectiveness of its registration statement or if the trust fails to become a going concern. The rule further requires the trustee to terminate the trust and distribute its assets if redemptions by the sponsor or any underwriter of umits that constitute a part of the unsold units result in the trust having a net worth of less than forty percent of the principal amount of the securities initially deposited in the trust. While the rule requires termination of a UIT and distribution of its assets when certain conditions are not met, the refund of sales charges to unitholders is conditioned upon the demand for such a refund by the unitholders. ${ }^{211}$ The demand requirement probably originates with section 14(a)(3)(C), which contains a similar demand provision with respect to a different exception to the minimun capital requirenents.

\section{F. Exchange Offers.}

Section 11 of the 1940 Act, ${ }^{212}$ which governs exchange offers, scarcely resenibles the provision that the Commission originally proposed and titled "recurrent promotion of investment conipanies." The Commission's draft legislation would have prohibited any promoter of a registered investnient company fron serving as adviser, officer, director, depositor, trustee, or principal underwriter if such person had promoted another investment conipany within the previous five years. The draft included a provision enabling investment companies to apply for exemption from the five-year prohibition. ${ }^{213}$ David Schenker explanied the provision by stating that "one cannot organize bank after bank, one camiot organize insurance conipany after insurance company, and we feel that they should not be allowed to organize imvestment trust after investment trust."214 Schenker criticized the imdustry's eniphasis on distribution and associated this emphasis with the need to contmue generating nerchandise to sell. As one investment lost its appeal, others were forned, and investors were persuaded to switch into the new conipamies. Schenker noted that as inany as six switches had occurred in the fixed trust area and that "switching operations" particularly disadvantaged sniall nivestors. ${ }^{215}$ Schenker conceded that the five-year moratoriunt on promotion was an arbitrary period, but he asserted that any shorter period would result in the recurrence of switching associated with fixed trusts in the

\footnotetext{
211. 17 C.F.R. $\S \S 270.14 a-3(a)(2)(i)$, (a)(3)(ii) (1987).

212. 15 U.S.C. $\$ 80 \mathrm{a}-11$ (1982).

213. Hearings 3580 , supra note 7 , at 9.

214. Id. at 227.

215. Id.; Hearings 10,065, supra note 204, at 59.
} 
1930 s. $^{216}$

Despite the criticism of the industry's distribution practices, section 11 changed significantly, partly because of industry opposition to the Commission's proposed legislation. 217 Section 11's focus shifted froin how inany investinent coinpanies one could organize during a given period to the price one could charge an investor who exchanged shares of one investinent coinpany for another. This shift inore closely addressed the staff's concern with exchanges-that investors were losing their principal as the result of inultiple exchanges. As enacted, section 11(c) required that the terins of any exchange involving UIT securities be approved in advance by the Commission or coinply with any rules prescribed by the Commission. In contrast, section 11(a) inerely required inutual funds to comply with Commission rules and to seek Commission approval ouly if the exchange offer were inade on the basis of something other than the relative net assets of the shares to be exchanged.218

In December 1986, the Commission proposed a rnle to exempt certain exchanges between UITs from section 11 coverage. ${ }^{219}$ Proposed rule 11c-1 would permit a UIT or its sponsor or principal underwriter to make an exchange offer to unitholders of another series of the same UIT, or to unitholders of another UIT having the same sponsor, on the basis of the relative net asset values of the respective units. The proposed rule would also permit the imposition of a sales load on such an exchange if, ainong other things, the sales load charged was no greater than the excess, if any, of the sales load applicable to the acquired unit over the sales load previously paid on the exchanged unit.220 Unlike its coinpamion, proposed rule 11a-3,221 which would exeinpt certain inutual fund exchanges, proposed rule $11 \mathrm{c}-1$ would not provide for the imposition of an administrative fee on an exchange transaction. ${ }^{222}$ The Commission explained that no UIT applicants had yet requested an exeinption to charge unitholders such fees.

216. Hearings 3580 , supra note 7 , at 227.

217. While at least one representative of the mdustry, albeit from the ranks of the management companies, acknowledged that the testimony revealed that switching occurred aniong fixed trusts, the industry nonetheless sought complete elimimation of section 11. Id. at 540, 1058.

218. The revision of section 11, like that of section 14, has been characterized as one of the major concessions made by the Commission in the 1940 Act. J. SellgMaN, supra note 203, at 228-29.

219. Offers of Exchange Involving Open-End Investment Companies and Unit Investment Trusts, Investment Company Act Release No. 15,494, [1986-1987 Transfer Binder] Fed. Sec. L. Rep. (CCH) If 84,051, at 88,387 (Dec. 23, 1986).

220. Id.

221. Id. at 88,386 .

222. Id. at 88,388 . 


\section{G. Pricing of Securities.}

Section 22 of the 1940 Act $^{223}$ regulates the pricing of redeemable securities issued by an investment company, whether $m$ the distribution, redemption, or repurchase context. Leaving aside subsection 22(d)'s much analyzed price-fixing exemption, which affects mutual funds and UITs equally and thus is not discussed herem, section 22 permits the Commission to prescribe rules governing the calculation of the price of investment company shares. These rules exist to eliminate or reduce as far as reasonably practicable any dilution im the value of such compames' outstanding securities, or other result unfair to the companies' current shareholders. ${ }^{224}$ These were not theoretical problems; witlı respect to UITs, Congress noted that dilution of shareholders' equity and riskless trading profits "have not been unusual."225

Rule $22 \mathrm{c}-\mathrm{1}^{226}$ was adopted to eliminate dilution and certain speculative trading practices associated witlı imvestment company redeemable securities, such as riskless trading, through the use of "forward pricing." 227 The rule subsequently was amended to treat UIT securities somewhat differently from other investment company redeemable securities. In 1979, the Commission proposed to codify existing exemptive orders for UITs by permitting a UIT sponsor to use backward pricing-to sell and repurchase trust units at a price based on the last busmess day of the previous week-for its secondary market.228 The Commission had granted these exemptions in recognition that the sponsor's secondary market activities were completely independent of the UIT and in no way involved the trust's assets. The proposed relief was conditioned upon the sponsor selling and repurchasing trust units at a price based on the offering-side evaluation. This practice would prevent the trust from being depleted, because liquidating unitholders would not have their units re-

223. 15 U.S.C. $\$ 80 \mathrm{a}-22$ (1982).

224. Section 22, as originally drafted by the Commission, also contained a provision allowing the Commission to challenge any offer of an investment company share that included an unconscionable or grossly excessive sales load. In the case of a UIT, for instance, the Commission would have been able to serve a notice upon the UIT's sponsor to appear and show cause why such sales load should not be prohibited. If after hearing the evidence the Commission found that the depositor was selling the securities at a price including an unconscionable or grossly excessive sales load, the Commission would have been able to order the company to cease and desist from selling at such price. Hearings 3580, supra note 7, at 15-16. Like other portions of the Commission's draft legislation, this provision was never enacted.

225. S. ReP. No. 1775, 76th Cong., 3d Sess. 8 (1940).

226. 17 C.F.R. $\S 270.22 \mathrm{c}-1$ (1987).

227. Prior to rule $22 c-1$, "backwards pricing" had existed, which created opportunities for riskless trading and dilution of an investment company's net asset value through its reliance on a price previously established.

228. Release 10,545 , supra note 167 , at 81,146 . 
deemed but would have their units repurchased by the sponsor at the "bid" price and thus realize the spread between the "bid" and "offering" price of the portfolio securities. The Commission proposed to allow a UIT to use the price computed on the last business day of each week, effective for all sales made during the following week, if, in the case of repurchases, the current bid price was not higher than the offering-side evaluation, computed on the last business day of the previous week, and if, in the case of resales, the offering-side evaluation, computed as of the last busmess day of the previous week, was not nore than one-half of one percent greater than the current offering price.

The Commission adopted the proposed amendinents to rule $22 \mathrm{c}-1$ with minor inodifications, ${ }^{229}$ but, iromically, the industry has moved away fron using the offering side for the secondary nuarket and thus no longer takes advantage of the nore favorable UIT pricing provisions of rule 22c-1. By late 1987, nearly all of the major UIT sponsors had begun using the bid side for their secondary nrarket activities. ${ }^{230}$ This, of course, leaves the unitholder imdifferent as to whether his shares are redeemed by the trust or repurchased by the trust sponsor. It also brings the secondary market for UIT securities back into conformity with the secondary market for most other securities, which trade on the bid side.

Backward pricing is still permitted, not only by rule $22 \mathrm{c}-1$, but also by exemptive relief given since the revision of that rule. Several UIT sponsors have obtained exemptive relief from rule 22c-1 in order to sell uints in their UITs on the first business day of the initial offering period at a public offering price determined as of the preceding day. ${ }^{231}$ They have sought this relief to prevent confusion among their investors who, upon reading the trusts' prospectuses, arguably have not realized that the prices shown therein would not be the prices they would pay and, indeed, that they would pay a higlier price if the price of the portfolio securities increased on or before the date of deposit. Although the registrants who have obtained this relief to use backward pricing have contended that such pricing would significantly reduce investor confusion, they have nonetheless stated that they would use backward pricing where it benefits

229. Release 10,690 , supra note 169 , at 81,779 .

230. As late as 1985 , a number of sponsors were still repurchasing at the offering side in the secondary market. See Merrill Lynch, Pierce, Fenner \& Smith Inc., Investment Company Act Release No. 14,684, 50 Fed. Reg. 34,563 (Aug. 19, 1985).

231. Salomon Brothers Unit Investment Trust, Insured Tax-Exenupt Series One, Investment Company Act Release Nos. 15,531 (Jan. 13, 1987) (second notice) \& 15,574 (Feb. 12, 1987) (order); First Trust of Insured Municipal Bonds, Investment Company Act Release Nos. 15,615 (Mar. 10, 1987) (notice) \& 15,688 (Apr. 16, 1987) (order); Kenuper Tax Exempt Trust, Investment Conupany Act Release Nos. 15,022 (Mar. 31, 1986) (notice) \& 15,064 (Apr. 22, 1986) (order). 
unitholders, that is, where the price of a unit decreases on the date of deposit.

\section{Other Fixed Portfolio Investment Vehicles}

Not all investment vehicles with fixed portfolios register as UITs under the 1940 Act. Some have registered as closed-end investment companies 232 and, because of their similarity to UITs, have received exemptive relief from certain provisions of the 1940 Act. Other fixed portfolio investment vehicles have received conditional exemptive relief from the entire 1940 Act and thus have not registered under the Act. A third type of fixed portfolio investment vehicle has qualified for the real estate company exception found in section 3(c)(5)(C) of the 1940 Act $^{233}$ and therefore need not register: under the 1940 Act. Not only have these compamies received exemptions from some or all of the 1940 Act, they also are sometimes entitled to special treatment under the 1933 Act.

\section{A. Closed-End Investment Companies.}

The Integrated ARROs Funds are two somewhat unique closed-end investment companies that obtained exemptive relief from several of the 1940 Act's provisions-sections 10(h)(1), 10(h)(2), 14(a), 17(a), 17(d), and 32(a)-on the basis of their organizational and operational similarity to UITs. Organized as grantor trusts, like many UITs, each ARROs Fund had a portfolio consisting of a group of specified real estate lease related contract rights that cannot change except in the case of a default or prepayment. ${ }^{234}$ Under the terms of the offering, the minimum purchase in an ARROs Fund was $\$ 10,000$, althougli the minimum purchase for an individual retirement account was only $\$ 2,000$. Moreover, in the initial offering, units were sold only to investors reasonably believed to have, either individually or in combmation with their spouses, a net worth of $\$ 75,000$, exclusive of their primcipal residence. ${ }^{235}$

232. Closed-end investment companies differ from UITs principally in that their portfolios are not fixed but managed, that they have a board of directors, and that they do not issue redeemable securities. See 15 U.S.C. $\$ 80 \mathrm{a}-5(\mathrm{a})(2)$ (1982).

233. Section $3(c)(5)(C)$ of the 1940 Act excepts from the defimition of investment company any company "not engaged in the business of issumg redeemable securities ... [that] is primarily engaged in ... purchasing or otherwise acquiring mortgages and other hens on and interests in real estate." Id. $\S 80 \mathrm{a}-3(\mathrm{c})(5)(\mathrm{C})$.

234. These contract rights represent amounts payable to the Funds' sponsor from privately offered real estate limited partnerships also organized by the Funds' sponsor. Integrated ARROs Fund, Investment Company Act Release Nos. 15,492 (Dec. 22, 1986) (notice) \& 15,693 (Apr. 21, 1987) (order).

235. Most UITs, on the other hand, are not sold so restrictively, and many rcquire a minimum investment of only $\$ 1000$. 
The ARROs Funds sought exemptive relief from section 17(a) of the 1940 Act so that they could acquire contract rights from their sponsor. Section 17(a)(1) of the 1940 Act generally prohibits au affiliated person of an mvestment company from selling securities or other property to that company, but section 17(a)(1)(C) excepts from that prohibition a sale involving solely securities deposited with the trustee of a UIT. The ARROs Funds asserted that the exception sliould apply to tliem because they, like a UIT, had a fixed portfolio fully identified and priced before mvestors purcliased their umits; thus the potential for abuse present in a management investment company did not exist. ${ }^{236}$ It is important to note that the ARROs Funds did agree to employ an independent evaluator with respect to the sale of the contract rights to the Funds. While many UITs utilize an imdependent evaluator, there is no requirement that the evaluator be imdependent, and, indeed, some evaluators are affiliated with the trust whose portfolio they evaluate.

Another "start-up" type of exemption received by the ARROs Funds involved the minimum capital requirements of section 14(a) of the 1940 Act. While UITs have historically received the exemptive relief from section 14(a) ${ }^{237}$ codified im rule 14a-3, ${ }^{238}$ such rehef has only been granted accompanied by certain conditions designed to return inoney to the investors if the trust shrinks below a certain size. The ARROs Funds, however, received unconditional rehef from section 14(a). The ARROs Funds did state that their sponsor would bear all costs of their organization (whicli UIT sponsors also bear); the mvestor presumably then would not lose tliose aniounts if the funds never got established. Because the exemptive relief was unconditional, however, the return of sales load ( $\mathrm{m}$ this case the underwriting spread) mandated by rule 14a-3 if a trust shrinks below a certain size was not required.

The ARROs Funds also obtained exemptive relief from sections 10(h)(1), 10(h)(2), 16(a), and 32(a) of the 1940 Act, which regnlate certain aspects of an investment company's board of directors. The funds successfully argued that these provisions were inapposite to the operation of an unmanaged, fixed portfolio imvestment company.

The Commission granted similar exemptive relief in the unusual situation of the College and University Facility Loan Trust. The College Trust, which, except for certain limited powers of substitution, has a fixed portfolio, was organized for the purpose of acquiring certain loans

236. While the justification for the exemptive relief revolved around section 17(a)(1), concerning the sale to the fund by the affiliate, the exemptive rehef given included sections $17(\mathrm{a})(2)$ and 17(a)(3) because exemptive relief was granted from all of section $17(\mathrm{a})$.

237. 15 U.S.C. $\$ 80 a-14$ (a) (1982).

238. 17 C.F.R. $\$ 270.14 a-3$ (1987). 
from the Umited States Department of Education in connection with the federal government's pilot loan asset sale program. ${ }^{239}$ The trust, like the ARROs Funds, obtained relief under the 1940 Act froin certain provisions affecting closed-end investment companies by asserting that it merited such relief because of its functional similarity to a UIT. ${ }^{240}$

Like the ARROs Funds, the College Trust needed exemptive relief from section 17(a) of the 1940 Act $^{241}$ to acquire its portfolio from the Department of Education, because the Department's status as either an "affiliated person" under section $2(a)(3)^{242}$ or a "promoter" under section $2(\mathrm{a})(30)^{243}$ of the 1940 Act triggered the prohibitions of section 17(a). ${ }^{244}$ The College Trust asserted that it deserved this relief im part because of its similarity to a UIT, which, as noted earlier, enjoys the section $17(a)(1)(C)$ statutory exception to the prohibition of section 17(a)(1). To ensure that the price it paid for the loans was fair and reasonable, the College Trust agreed to retain an imdependent evaluator to determine the fairness of the consideration paid for the loans.

Although the College Trust received exenptive relief similar to that received by the ARROs Funds with respect to the 1940 Act provisions governing management investment companies that are essentially inapplicable to an unmanaged company with a fixed portfolio, certain differences between the College Trust and the ARROs Funds should be noted. First, because the College 'Trust had a considerably more complex capital structure than the ARROs Funds-it was issuing debt securities as well as equity-it needed exemptive rehef fron 1 the capital structure and equal voting provisions of section 18. In seeking such relief, the College Trust noted that the equal voting rights provision of section 18(i) does not apply to UITs and that the trust would operate essentially as a UIT. Indeed, the College Trust could lave argued that no portion of section 18 applies to UITs and that, therefore, none of its provisions should apply to

239. Investment Company Act Release Nos. 15,903 (July 31, 1987) (notice) \& 15,990 (Sept. 18, 1987) (order). This was a complex exemption, and the application for exemptive relief should be analyzed in conjunction witl the notice. See Application of College and University Facility Loan Trust, File No. 812-6807. For more information on the federal government's pilot loan asset sale, see The Omnibus Budget Reconciliation Act of 1987, Pub. L. No. 99-509, § 7005, 100 Stat. 1874 (1986).

240. The College Trust received exemptive relief from sections 10(h), 14(a), 16(a), 17(a), 18(a), 18(c), 18(i) and 32(a).

241. 15 U.S.C. $\$ 80 \mathrm{a}-17(\mathrm{a})$.

242. Id. $\S 80 \mathrm{a}-2(\mathrm{a})(3)$.

243. Id. $\$ 80 \mathrm{a}-2(\mathrm{a})(30)$.

244. Section 2(a)(3)(F) of the 1940 Act defines the depositor of an unincorporated investment company not having a board of directors as an "affiliate" of such company. Id. $\S 80 \mathrm{a}-2(\mathrm{a})(3)(\mathrm{F})$. Section 2(a)(30) of the 1940 Act defines "promoter" of a company as a person who is directing, or has within one ycar directed, the organization of sucl company. Id. $\S 80 \mathrm{a}-2(\mathrm{a})(30)$. 
an entity that is essentially a UIT. It bears einphasizing that while certain provisions of section 18 apply to all management investenent companies, for example, paragraphs (d) and (i), and other provisions affect either closed- or open-end companies, for exaunple, paragraphs (a), (c), (e), and (f), no provision of section 18 applies to UITs.

A second distinction between the College Trust and the ARROs Funds involves section 26. The College Trust agreed to be subject to niost provisions of section 26 of the 1940 Act as though it were a UIT, but did not agree to be subject to subsections (a)(2)(B) and (C). This limitation was predicated on the Trust's desire to pay certain closing and servicing costs, customary with asset-backed financing vehicles, associated with the loans bought by the Trust. Thus, while the Trust agreed to be subject to the key UIT provision of the 1940 Act, the exception removed the Trust from one of the integral subprovisions of that provision, leaving open to question the effectiveness of the agreement. Of course, the Trust agreed to disclose the closing and servicing costs in its prospectus. In any event, because of the unique nature of the applicants and the strong public policy reasons for granting exemptive rehef, the precedential value of this exemption granted in connection with the government loan sales program is probably rather limited.

\section{B. Fixed Portfolio Investment Companies Exempted From the 1940 Act.}

Some fixed portfolio investnient velicles have obtained exemptive rehief from the entire 1940 Act. Of those obtaining such relief, some have invested their proceeds solely in nortgage-related securities known generically as "collateralized mortgage obligations," while others have invested their proceeds in bonds issued by an international financial institution or foreign government and have issued "stripped" securities representing interests in the component parts (principal or interest) of tliose bonds.

1. Collateralized Mortgage Obligation Trusts. Collateralized mortgage obligation trnsts (CMO trusts) resemble the traditional Government National Mortgage Association (GNMA) UIT in that both serve as investment vehicles for investors seeking access to the mortgage nıarket in a diversified, indirect faslion. In addition, botlı CMO trnsts and GNMA UITs are often created witl a bank acting as trustee. ${ }^{245}$ Yet

245. See, e.g., Triad Mortgage Acceptance Corp., Investment Company Act Release Nos. 15,904 (July 31, 1987) (notice) \& 15,956 (Sept. 1, 1987) (order) [hereinafter Triad Releases]; CityFed Funding Corp., Investment Company Act Release Nos. 15,795 (June 10, 1987) (notice) \& 15,857 (July 2, 1987) (order) [hereinafter CityFed Releases]. 
there are differences between the two. An interest in a GNMA UIT is an equity interest in a pool of GNMA certificates, whereas the interests sold in a CMO trust are generally debt interests-bonds secured by various types of inortgage interesis. This distinction has blurred, however, as CMO trusts have begun to sell not only bonds, but also the equity residual interests in themselves to institutional investors. Another difference is that CMO trusts, unlike UITs, do not issue redeemable securities.

A third and critical distinction lies in the varying degree to which these companies maintain a fixed portfohio. As a result of the definition of a UIT, the staff of the Commission beheves that substitution within the portfoho of a UIT can only occur under extraordinary circumstances-circumstances imdicating that the creditworthiness or economic viability of the issuer of the portfolio security is seriously in doubt. ${ }^{246}$ This interpretation ensures that a UIT will retain its fixed nature. CMO trusts, on the other hand, are only moderately fixed in comparison. While ehminated portfolio securities must be replaced by mortgage securities of equal or better quality with similar payinent terms and cash flow, as much as forty percent of the aggregate face amount of the portfolio securities initially purchased nay be substituted; in no event, however, may any new portfolio security be substituted for any substituted security. ${ }^{247}$

Although the investors in a CMO trust exempted from all provisions of the 1940 Act may not enjoy the same protections as investors in a UIT, they are not left unprotected. The Commission has attached several conditions to the exemptive relief it has granted CMO trusts. It has required (1) that custody of the CMO trust's assets rest with an entity unaffiliated ${ }^{248}$ with the sponsor; (2) that an independent public accountant annually audit the books and records of the trust; and (3) that any offering of equity interests not constitute a public offering within the meaning of section $4(2)$ of the 1933 Act, ${ }^{249}$ and result in no more than 100 beneficial owners. ${ }^{250}$

Approximately 120 UIT series invest in GNMAs and have over $\$ 2.5$ billion in assets. Only 82 GNMA UIT series with less than \$: billion in assets existed a year ago. INVESTMENT Co. INST., RePORT ON TOTAL OUTSTANDING UNIT INVESTMENT TRUSTS FOR THE YEAR 1985 (1986).

246. Paine Webber Equity Trust, Growth Stock Series (pub. avail. Sept. 24, 1986); Release 6693, supra note 111 , at 88,563 .

247. See, e.g., Triad Releases, supra note 245; CityFed Releases, supra note 245.

248. Rule 405 under the 1933 Act, 17 C.F.R. $\$ 230.405$ (1987), not section 2(a)(3) of the 1940 Act, 15 U.S.C. $\S 80 \mathrm{a}-2(\mathrm{a})(3)(1982)$, defines "affiliate" in these exemptive applications.

249. 15 U.S.C. $\$ 77 \mathrm{~d}(2)$ (1982).

250. See, e.g., Triad Releases, supra note 245; CityFed Releases, supra note 245. Another condition to obtaining exemptive relief requires a CMO trust that is issuing bonds to register the bonds under the 1933 Act unless they are exempt from registration pursuant to section 4(2) of that Act. This condition is not particularly onerous, however, since it prohibits only certain "limited offers" 
2. "Stripped" Securities Companies. Several major investment bankers liave recently obtained exemptive relief from the entire 1940 Act in conjunction witl their offering of "stripped" securities, that is, the component parts of interest-bearing bonds issued by an international financial institution such as the World Bank, or by a foreign government. ${ }^{251}$ These investment bankers have asserted that the potential mvestment companies would imcrease hquidity by providing a more flexible market for debt securities issued by foreign governments and international financial institutions.

Several similarities between these types of potential investment companies and UITs exist. First, the selection of the stripped portfolio securities is made before the sale of interests in the stripped securities and, as with UITs, investors know exactly what they are purchasing. Second, although they are not required to do so, the investment bankers state that they expect to maintain a secondary market in the securities tliey issue. Third, the investment bankers sponsoring the potential investinent company purchase the bonds that constitute the portfolio securities and deposit thein with a bank. Finally, the portfolio securities acquired by the potential investment coinpany are held by a bank pursuant to a custody agreement meeting the requirements imposed upon UITs by section 26(a) of the 1940 Act.

Despite these similarities, two integral differences between "stripped" securities companies and UITs exist. As with the CMO trusts, the stripped securities coinpanies do not issue redeemable securities. Furthermore, the securities issued by these comparies are sold only to institutional investors who ineet the definition of "accredited investor" under Regulation D of the 1933 Act $^{252}$ and who have sufficient knowledge and experience to evaluate the risks associated with investing in securities representing interests in the principal or interest payments of the underlying bonds. This institutional investor limitation has allowed applicants to assert that their proposed transaction are not of the type that need to be regulated under the 1940 Act.

governed by rules 504 and 505 of regulation D. See 17 C.F.R. $\$ \S 230.504 .505$ (1987). The restrictions on a CMO trust's equity offering apparently emanate from the provisions of section 3(c)(1) of the 1940 Act, which excepts from the definition of investment company "[a]ny issuer whose outstanding securities ... are beneficially owned by not more than one hundred persons and which is not making and does not presently propose to make a public offering of its securities." 15 U.S.C. $\S 80 \mathrm{a}-3$ (c)(1) (1982).

251. Kidder, Peabody \& Co., Investment Company Act Release Nos. 15,801, 52 Fed. Reg. 23,236 (June 11, 1987) (notice) \& 15,861 (July 2, 1987) (order); Shearson Lehman Bros., Investment Company Act Release Nos. 15,799, 52 Fed. Reg. 23,244 (June 11, 1987) (notice) \& 15,860 (July 2, 1987) (order).

252. Rule 501 of regulation $D$ defines the term "accredited investor." 17 C.F.R. $\$ 230.501$ (a) (1987). 


\section{Section 3(c)(5)(C) Companies.}

Some fixed portfolio imvestment companies fall within section $3(c)(5)(C)$ 's protection. That provision excepts from the definition of investment coinpany all issuers that do not issue redeenable securities and that are primarily engaged in purchasing or otlerwise acquiring inortgages or otler interests in real estate. Sucli issuers are thus not subject to the 1940 Act and need not go througl the exeinptive process to attain sucli status. They differ from UITs principally because they cannot issue redeemable securities, although, like UITs, they can make a secondary market in their shares. The prohibition on issumg redeemable securities was not always part of section $3(c)(5)(C)$. In fact, it only becanie part of that section as a result of the 1970 ainendments to the 1940 Act, which extended the coverage of the 1940 Act to issuers seeking to capitalize on the popularity of mutual funds..$^{253}$ A second, pragmatic difference between section $3(c)(5)(C)$ companies and UITs is that UITs investing in real estate tend to do so througli GNMA and other government-backed securities, while section $3(c)(5)(C)$ compames tend to invest in a wide variety of other types of real estate interests, including leasehold interests in real estate and construction period inortgage loans. ${ }^{254}$

Despite these differences, a company excepted from the 1940 Act througli section $3(c)(5)(C)$ can closely reseinble a UIT that invests im nortgages. The provision in section $3(\mathrm{c})(5)(\mathrm{C})$ that requires the coinpany to be "primarily engaged" in the business of purcliasing or otherwise acquiring real estate interests does not require that such a company actively inanage its portfolio. In fact, sucli a coinpany can be a passive, fixed investment trust without employees, officers, an investment adviser, or a board of directors. ${ }^{255}$

The contours of section 3(c)(5)(C) have been extensively probed, especially over the last decarle. While the redeemable securities elemnent has not received a great deal of scrutiny, the "primarily engaged" and the "mortgages and other liens on or interests in real estate" requirements have received much attention. While the staff of the Coinmission used to interpret the "primarily engaged" provision as requiring at least sixtyfive percent of a company's assets to consist of real estate interests, it has moved to a fifty-five percent requirement. ${ }^{256}$ Recently, the staff of the

253. See S. REP. No. 184, 91 st Cong., 1st Sess. 37 (1969), reprinted in 1970 U.S. CoDE CoNG. \& ADMIN. NEws, 4897, 4932-33 (discussing section 3(c)(6) which was later redesignated section 3(c)(5); H.R. REP. No. 1382, 91 st Cong., 2d Sess. 17 (1970).

254. Health Facility Credit Corp. (pub. avail. Feb. 6, 1985); Northwestern Ohio Building \& Construction Trades Foundation (pub. avail. May 21, 1984).

255. McDonald \& Company Securities, 1nc. (pub. avail. Dec. 14, 1983).

256. Salomon Brothers Mortgage Securities, Inc. (pub. avail. Nov. 8, 1983). 
Commission has begun to require that the remaining forty-five percent of the company's assets consist primarily of real estate related investments. ${ }^{257}$ The "mortgages or other interests in real estate" requirement has received scrutiny as imtense as that given any other element of section $3(c)(5)(C)$. The staff of the Commission, for instance, decided that GNMA, Federal National Mortgage Association (FNMA), or Federal Home Loan Mortgage Corporation (FHLMC) certificates comprising an undivided interest in the entire pool of mortgages backing the certificates (whole-pool certificates) qualify under section 3(c)(5)(C), ${ }^{258}$ but that the same certificates representing a proportionate interest in a pool of mortgages (partial-pool certificates) do not. 259

\section{The 1933 Act and Mortgage Securities.}

While many UITs qualify for liberalized registration treatinent under the 1933 Act as a result of rule 487260 irrespective of whether they invest in inortgage-related securities, certain fixed portfoho companies not subject to the 1940 Act may qualify for the hiberalized registration treatment afforded by rule 415 of the 1933 Act $^{261}$-the shelf-registration rule-if they invest in mortgage-related securities. When adopted on a teinporary basis in $1982,{ }^{262}$ rule 415 did not exphcitly extend relief to mortgage-related securities. When adopted on a permanent basis, eighteen inonths later, ${ }^{263}$ rule 415 contained a provision exphicitly providing shelf registration for such securities. ${ }^{264}$ The release adopting the final rule stated that mortgage-related securities, such as mortgage-backed debt and mortgage participation or pass-through certificates, previously had been eligible for shelf registration under a more general provision of the rule.

The shelf-registration rule exphicitly excludes UITs (and mutual

257. Salomon Brothers Mortgage Securities, Inc. (pub. avail. June 16, 1985).

258. Landmark Funding (pub. avail. Sept. 20, 1984); Equibank (pub. avail. Aug. 29, 1983); American Home Fimance Mortgage Corp. (pub. avail. May 11, 1981).

259. Nottimgham Realty Securities, Inc. (pub. avail. Apr. 19, 1984); Arlington Investment Co. (pub. avail. Aug. 31, 1974).

260. 17 C.F.R. § 230.487 (1987).

261. Id. $\S 230.415$.

262. Securities Act Release No. 6383 (Mar. 2, 1982).

263. Shelf Registration, Securities Act Release No. 6499, [1983-1984 Transfer Bimder] Fed. Sec. L. Rep. (CCH) If 83,449, at 86,335 (Nov. 17, 1983) [heremafter Release 6499]. The Secondary Mortgage Market Enhancement Act of 1984, Pub. L. No. 98-440, 98 Stat. 1689, would have reqnired the Commission to provide a permanent shelf registration procedure for mortgage-backed securities, but that requirement was eliminated as a result of the adoption, on a permanent basis, of rule 415. House Comm. ON ENERgY AND COMMERCE, SECONDARY MORTGAGe MARKET ENHANCEMENT ACT of 1983, H.R. ReP. No. 98-994, 98th Cong., 2d Sess. 14 (1984).

264. 17 C.F.R. $\$ 230.415$ (a)(1)(vii) (1987); see Release 6499, supra note 263, at 86,342. 
funds) registered under the 1940 Act from its provisions; ${ }^{265}$ therefore, fixed portfolio investment vehicles seeking to rely on rule 415 must avoid being subject to the 1940 A.ct by, for example, structuring themselves to come within section 3(c)(5)(C) of that act or obtaining exemptive relief pursuant to section 6(c). Because the rule was modified to permit rehance upon it by closed-end imvestinent coinpames, ${ }^{266}$ fixed portfolio investinent vehicles like the ARROs Funds could have relied upon it.

The significance of rule 415 is that, like rule 487 , it gives issuers control over when offerings are brought to market and allows them to comply with 1933 Act registration requirements while basing their decisions on market and business factors rather than Commission processing schedules. A fixed portfoho company mvesting in mortgages or mortgage-related securities (an MRS issuer) can register a large quantity of securities by using a registration statement containing what is referred to as a "core prospectus." The core prospectus contains disclosures about each possible type of mortgage that could forn part of a pool to be offered. It is supplennented by an offering-specific document that contains inore detail about the particular offering being made through that document, such as the type, yield, and maturity of the mortgages comprising the pool. The offering-specific document together with the core prospectus make up the preliminary prospectus used to solicit indications of interest in a specific offering. The MRS issuer generally solicits interest in a specific shelf offering without first asseinbling the portfolio of mortgage-related securities. Incleed, although investors know what type of mortgage-related security the issuer intends to purchase with the proceeds, it is not necessary for the mortgages to be purchased before the securities are sold; ${ }^{267}$ moreover, the offering-specific document does not identify specific mortgages or mortgage-related securities. Investors thus purchase interests in an unidentified pool of mortgages. ${ }^{268}$

Aside from the fact that a rule 487 offering is regulated by the 1940 Act, fixed portfolio offerings registered under rule 415 differ from those filed under rule $487 \mathrm{im}$ two respects. First, when a UIT sponsor designates a tiine and date for the effectiveness of its registration statement under rule 487 , the filing that becomes effective must contain a portfolio of specified securities. The very essence of a UIT, in fact, imvolves an investor who "exercises his own judgment, because he is ordi-

265. 17 C.F.R. $\S 230.415$ (b) (198').

266. Securities Act Release No. 6334, Fed. Sec. L. Rep. (CCH) No. 926 (Second Extra Edition) (Aug. 13, 1981).

267. Release 6499 , supra note 263 , at 86,342 .

268. Release 6693 , supra note 111 , at 88,561 . 
narily shown the hist of securities in which his funds will be invested."269 This, of course, differs fundamentally froin the situation with MRS issuers, who do not identify specific inortgage-related securities in their offering documents. Second, under rule 487, each series of a UIT as well as the UIT sponsor is a separate issuer under the 1933 Act.270 Under rule 415 , however, the securities offered under a shelf registration are in most instances issued by a single issuer. ${ }^{271}$ This distinction is significant not only because under rule 487 there exist two potentially liable issuers-the series and its sponsor-in contrast to the single issuer under rule 415 , but because of its implications for the entire registration process. Since eacl series is considered a separate issuer, each series inust be offered pursuant to its own prospectus, a prospectus that inust be kept current under section 10(a)(3) of the 1933 Act because the sponsor of the series generally makes a secondary market in units of the series.

\section{CONCLUSION}

UITs have emerged as a popular consunier imvestment. Like their fixed trust predecessors, a UIT offers an alteruative to mutual funds and other inanaged investment vehicles. Like a mutual fund, a UIT offers diversity at an affordable price. Unlike a inutual fund, lowever, a UIT offers certainty: an investor in a UIT knows what securities his UIT owns and will always own-subject only to limited substitution and elimination powers-before he purchases sliares in the UIT. Because of its relatively fixed nature, the UIT seeins to be most useful as a vehicle for efficiently investing in debt securities. Thus, as long as debt securities are attractive investinents, UITs should remain popular. The other fixed portfolio investment vehicles may be aberrational, although the ones investing in real estate and mortgage-backed securities seem somewhat entrenched.

The growing popularity of UITs lias not gone unnoticed. The banking industry has quietly gotten involved as more than just the trustee to UITs, and the Cliairman of the Commission recently specified the underwriting of UITs as a potential bank activity that would liave to come under SEC jurisdiction as a result of any legislation expanding the per-

269. Hearings 3580 , supra note 7 , at 300 .

270. Release 6401 , supra note 100 , at 85,060 .

271. Certain MRS issuers use rule 415 to make periodic offerings of securities where each offering involves the creation of a discrete trust containing the pool of securities to be offered. For the purpose of reporting under the 1934 Act, each trust files as a separate issuer. While each offering proceeds through the use of a prospectus filed under rule 424, 17 C.F.R. $\$ 230.424$ (1987), without a new 1933 Act registration statement identifying the new trust as an issuer, it could be asserted that each trust is a separate issuer under the 1933 Act as well, see Release 6693, supra note 111, at $88,560-61$. 
missible securities activities of banks. 272 In addition to the UIT's growing popularity with consumers and with the financial services industry, the evolution of the securities laws and regulations affecting UITs deserves careful attention. The treatment of UITs under the 1933 and 1940 Acts has undergone the most dranatic changes with respect to registration provisions, but treatment under the regulatory provisions of the 1940 Act has changed as well. Further changes in the legal landscape seem imminent, particularly in the area of registration forms and rules.

272. Ruder Shifts Stance on Banks' Role in Brokerage, Am. Banker, Dec. 3, 1987, at 1, col. 2 \& 30, col. 4 . 